\title{
Effects of herbicide treatments on biotic components in regenerating northern forests
}

\author{
by R. A. Lautenschlager ${ }^{1,2}$ and Thomas P. Sullivan ${ }^{3}$
}

We reviewed literature, primarily since 1990, that documents effects of herbicide treatments on major biotic components in northern forested ecosystems. Vegetation changes are responsible for changes in all other biotic components. Non-conifer vegetation is commonly reduced for two to five years following broadcast herbicide treatments. Fungal components, however, seem relatively unaffected. Short-term vegetation reductions in cover, density, and related biomass, if they occur, are species and/or vegetation group specific; longer-term changes are linked to conifer stocking, site quality, and the ability of conifers to dominate treated sites. Herbicide treatments do not reduce, and may increase, stand- and landscape-level plant species richness. Those treatments seldom produce monocultures when used by foresters for boreal or boreal mixedwood management. The active ingredients in the herbicide products used in forestry in northern ecosystems have no direct effect on the general health (survival, growth, reproduction) of animals in treated areas. Specific, stand-level forest management practices, particularly effects of site preparation and conifer release, must be examined in relation to the landscape mosaic and the desired future forest conditions. At broad scales, across boreal and boreal mixedwood ecosystems, conifers have been consistently replaced by hardwoods since Europeans began harvesting timber from those ecosystems. Herbicides provide a safe, effective tool for restoring conifers in previously conifer-dominated ecosystems. Forest scientists presently have a reasonable understanding of effects of a variety of herbicide treatments on conifer growth and a variety of environmental components. However, they need to continually update that understanding relative to treatments (replicates, chemicals, combinations, or timing) that may be used in the future.

Key words: amphibians, conifer release, deer, disturbance, environment, glyphosate, herbicides, invertebrates, landscape, moose, reptiles, site preparation, small mammals, songbirds, snowshoe hare, triclopyr, vegetation

Nous avons révisé la littérature, principalement depuis 1990, qui documente les effets des traitements phytocides sur les principaux éléments biotiques dans les écosystèmes forestiers nordiques. Les modifications apportées à la végétation sont responsables des changements survenus chez tous les autres éléments biotiques. La végétation non-résineuse est habituellement réduite de deux à cinq ans suivant les traitements d'épandage généralisé de phytocides. Les composantes fongiques, cependant, ne semblent relativement pas affectées. Les réductions à court terme de la végétation au niveau du couvert, de la densité et de la biomasse impliquée, si tel est le cas, touchent spécifiquement certaines espèces ou groupe de plantes; les changements à long terme sont reliés au nombre de semis de résineux, la qualité de la station et la capacité des résineux à dominer dans les sites traités. Les traitements phytocides ne réduisent pas, et pourraient accroître la variété d'espèces de plantes au niveau du peuplement et du paysage. Ces traitements produisent rarement des monocultures lorsque utilisés par des forestiers qui aménagent les forêts boréales ou mélangées nordiques. Les ingrédients actifs dans les produits phytocides utilisés en foresterie dans les écosystèmes nordiques n'ont pas d'effet direct sur la santé globale (survie, croissance, reproduction) des animaux dans les zones traitées. Les pratiques d'aménagement forestier spécifiques au niveau du peuplement, notamment les effets de la préparation du site et le dégagement des résineux, doivent être examinées en fonction de la mosaïque du paysage et des conditions forestières futures souhaitées. De façon générale, dans les écosystèmes boréaux et les forêts mélangées nordiques, les résineux ont été systématiquement remplacés par les feuillus depuis que les Européens ont commencé la récolte du bois dans ces écosystèmes. Les phytocides s'avère un outil sécuritaire et efficace pour réintroduire les résineux dans des écosystèmes qui étaient dominés antérieurement par les résineux. Les chercheurs forestiers ont actuellement une compréhension raisonnable des effets de plusieurs traitements phytocides sur la croissance des résineux et la variété des composantes environnementales. Cependant, ils doivent continuellement mettre à jour leur compréhension relative aux traitements (répétitions, éléments chimiques, combinaisons ou moment d'application) qui pourraient être utilisés dans l'avenir.

Mots- clés : amphibiens, dégagement des résineux, chevreuil, perturbation, environnement, glyphosate, phytocides, invertébrés, paysage, orignal, reptiles, préparation du site, petits mammifères, oiseaux chanteurs, lièvre d'Amérique, triclopyr, végétation

\section{Introduction}

During the last five decades, silvicultural intensity has increased gradually in northern forested ecosystems. Although Clawson (1975) provided the framework nearly three decades ago, identifying specific use zones within broad management areas has re-emerged as a forest management recommendation

${ }^{1}$ Ontario Ministry of Natural Resources, Ontario Forest Research Institute, Sault Ste. Marie, ON P6A 2E5.

${ }^{2}$ Current Address: Atlantic Canada Conservation Data Centre, PO Box 6416, Sackville, NB. E4L 1G6. E-mail: rlautenschlager@mta.ca.

${ }^{3}$ Applied Mammal Research Institute, 11010 Mitchell Ave., R.R. No. 3, Site

46, Comp. 18, Summerland, BC VOH 1Z0. E-mail: Sullivan@telus.net.

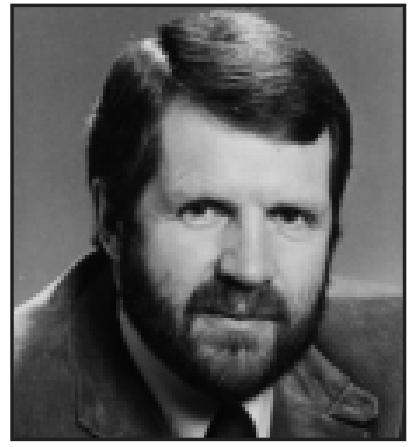

R. A. Lautenschlager

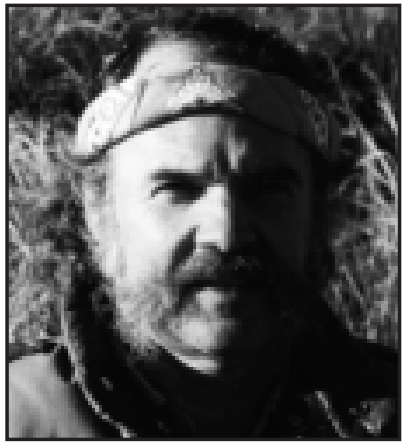

Thomas P. Sullivan 
associated with intensive silviculture (Seymour and McCormack 1989; Seymour and Hunter 1992; Binkley 1997; Taylor 1999; Lautenschlager 1999a, 2000). Intensive silviculture can focus on a variety of species or species groups (conifers, hardwoods, mixedwoods) any time during the rotation. However, fibre production benefits, especially for conifers, have consistently come from treatments that occur during the establishment phase after harvesting or natural disturbances (Lautenschlager 2000). Depending on the site, treatments during that phase are used to reduce the abundance of non-conifer competition from pioneer species. The severity of competition experienced by conifers varies with competing species and increases with increasing abundance of competitors (Walstad and Kuch 1987; Lautenschlager 1995, 1999b; Wagner et al. 1999).

Individually and collectively, early seral plant species compete with conifer seedlings for resources (Radosevich and Osteryoung 1987, Lautenschlager 1999b). Volume growth of conifer seedlings consistently increases after competition is controlled (Walstad and Kuch 1987, Newton et al. 1992, Freedman et al. 1993, Lautenschlager 1995, Wagner et al. 1999). This and other management realities have led to the suggestion that repeated herbicide treatments, or other silvicultural practices (e.g., genetic improvement, fertilization), could produce an eight-fold increase in conifer production on selected sites in Canadian forests (Taylor 1999, Lautenschlager 2000). Conifer growth responses, however, are not examined in detail in this paper. Interested readers should see Walstad and Kuch (1987) for an overview of those responses in North American forests.

Not surprisingly, intensive silvicultural techniques with proven operational benefits - site preparation and conifer release-are now commonly used in many managed northern conifer and mixedwood ecosystems (Lautenschlager 2000). Where conifers have been planted, and competition has been controlled, primarily via spray solutions containing herbicide products, conifer growth has increased in direct proportion to the degree and duration of the control received (Walstad and Kuch 1987, Wagner et al. 1999). However, conifer growth benefits associated with early and repeated release have both financial and social consequences. Early release is considered cost and biologically effective, but most people (publics) in North America are opposed to herbicide use, especially aerial use (Lautenschlager 1986, Smith 1986, Freedman 1991, Lautenschlager et al. 1998, Wagner et al. 1998), at any time. Herbicide applications have led to conflicts with concerned publics and repeated applications could increase the probability of conflicts (Lautenschlager 2000).

Public concerns about herbicide use in forestry seem based on a combination of philosophy, caution, and lack of scientific information and/or understanding. Although the views of publics and stakeholder groups must be considered when making responsible forest management decisions (CCFM 1995a, Lautenschlager 1999c, Messier and Kneeshaw 1999, Lautenschlager et al. 2000), natural resource management decision makers generally believe that science should provide the foundation for those decisions (CCFM 1995a, Lautenschlager et al. 2000, Lautenschlager 2001, Willick 2001).

Historically, research examining environmental consequences of herbicide use has been relatively inconsistent in terms of the chemicals and post-treatment periods studied (Lautenschlager 1993a). For instance, some tests have been conduct- ed using the active ingredients found in herbicide products, while others have been conducted using the formulated products themselves (Roshon et al. 1999). The surfactants (which may have properties similar to soap) in some products, as well as some active ingredients, can cause products to be slightly to moderately toxic to zooplankton, invertebrates, fish, and amphibians (Hildebrand et al. 1980, Sullivan et al. 1981, Mitchell et al. 1987, Scrivener and Carruthers 1989, Roshon et al. 1999). However, most scientists who have studied the toxicity of the herbicide active ingredients and/or the formulated products have concluded that when used at recommended rates, under normal-use scenarios, herbicide spray solutions used in forestry for site preparation or conifer release pose minimal toxicological hazard for terrestrial vertebrates or risk of bioaccumulation in the environment (Morrison and Meslow 1983; Newton et al. 1984; Atkinson 1985; Sullivan 1985, 1990a,b; Newton et al. 1989; Giesy et al. 2000; Williams et al. 2000).

It has been nearly a decade since the last review of effects of forest herbicides on major environmental components (Lautenschlager 1993a,b). That combined with an increased interest in intensive silviculture and the publication of additional studies, suggest that a review at this time would be valuable. The objective of this review is to provide a synthesis of recent literature so that operational foresters, managers, and policy makers can make informed decisions and better address the concerns of the variety of interested publics. This review updates Lautenschlager's (1993a) earlier work that synthesized the previously available literature examining effects of herbicide treatments, primarily for conifer release, on the major wildlife groups found in northern forested ecosystems. To avoid duplication, the current review concentrates on literature that was not examined or not stressed in the earlier review or has become available since then. In addition, the current review examines effects on vegetation and attempts to draw conclusions at stand and landscape levels. Categorized abstracts of much of the reviewed literature are found in Sullivan and Sullivan (2000) and Mihajlovich (2001).

\section{Review}

\section{Vegetation (Table 1)}

Abundance and Diversity

Spray solutions containing herbicides used for site preparation and/or conifer release reduce competitive biomass and release young conifers from non-conifer competition. Depending on geographic location, that competition often is from alder (Alnus), willow (Salix), poplar (Populus), raspberry (Rubus), birch (Betula), maple (Acer), cherry (Prunus), and a variety of herbaceous species and/or groups of species, such as grasses, sedges, and rushes. Stand-level biomass reductions of non-conifer vegetation (commonly 50-70\% during the first year after treatment, but varying by vegetative group - Fig. 1) have consistently followed site-preparation and conifer release treatments in a variety of northern ecosystems (Newton et al. 1992; Pitt et al. 1992, 1993, 2000; Freedman et al. 1993; Raymond et al. 1996; Bell et al. 1997; Kelly et al. 1998; Sullivan et al. 1998a; Vreeland et al. 1998; Gagné et al. 1999; Lautenschlager et al. 1999; Lindgren and Sullivan 2001). However, operationally effective conifer release treatments generally eliminate few, if any, of the species from treated sites (Morrison and Meslow 1983; Newton et al. 1989; Santillo et al. 1989; Lautenschlager 1990,1993a; Horsley 1994; Bell and Newmaster 1998; 


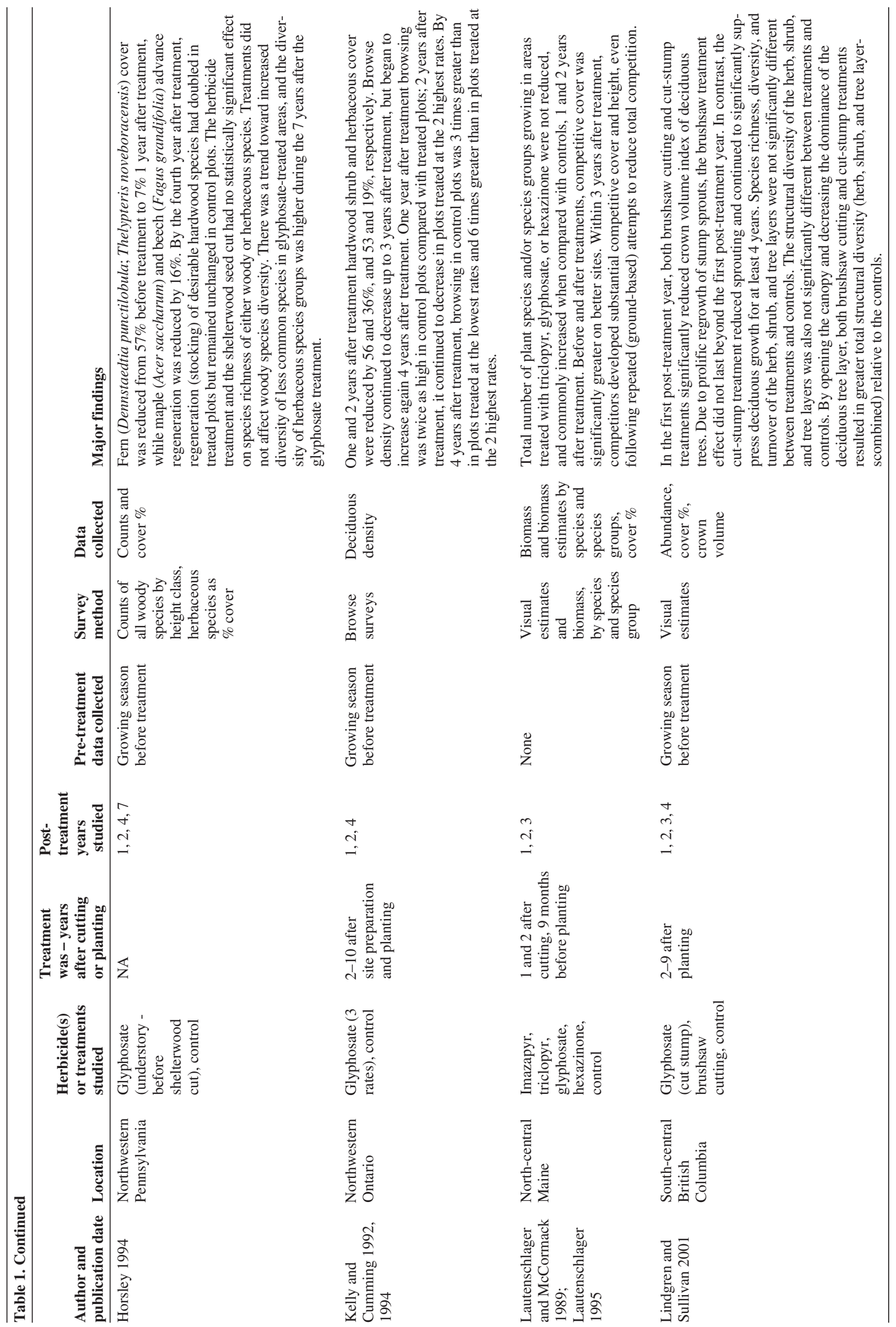




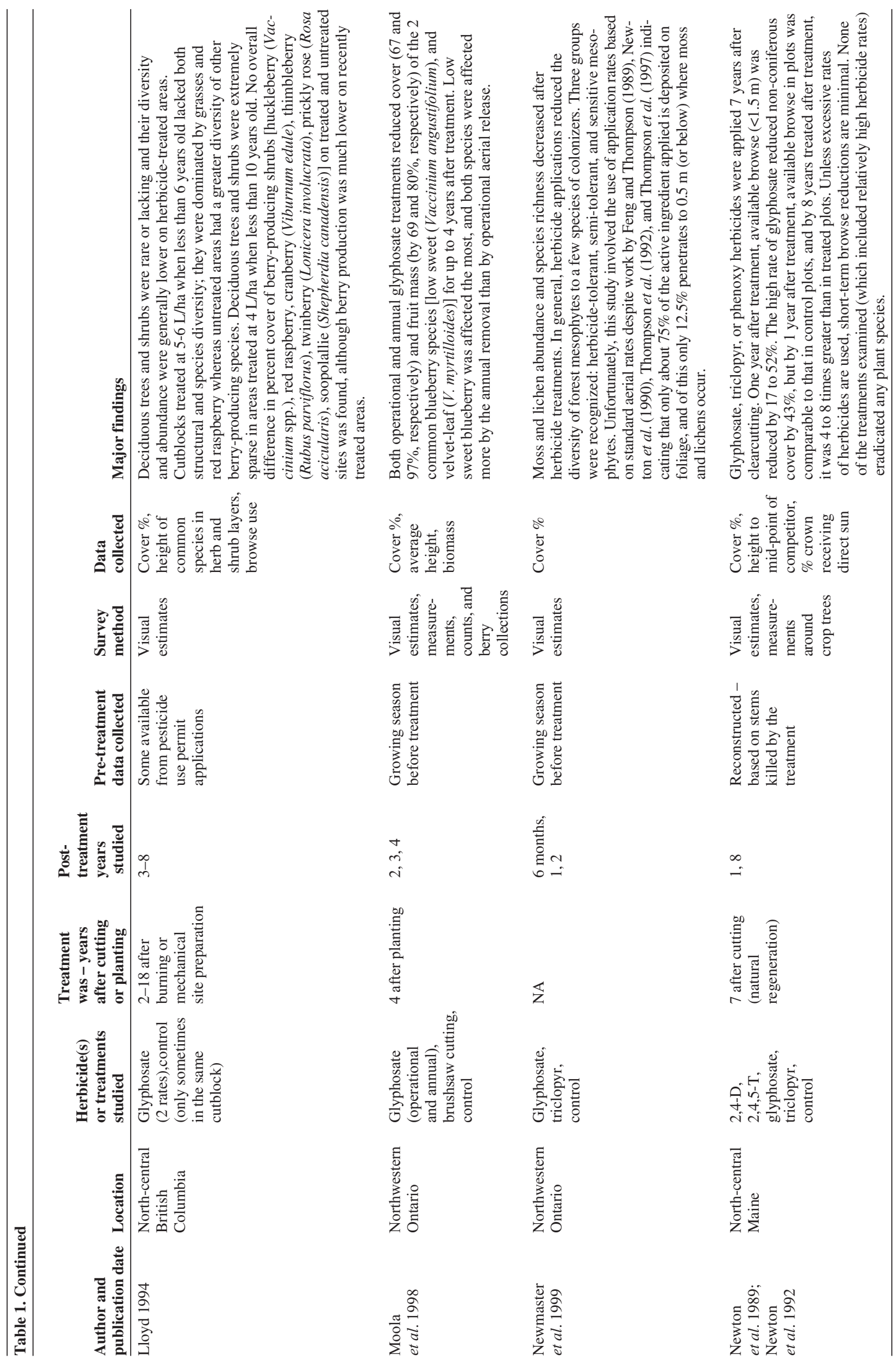




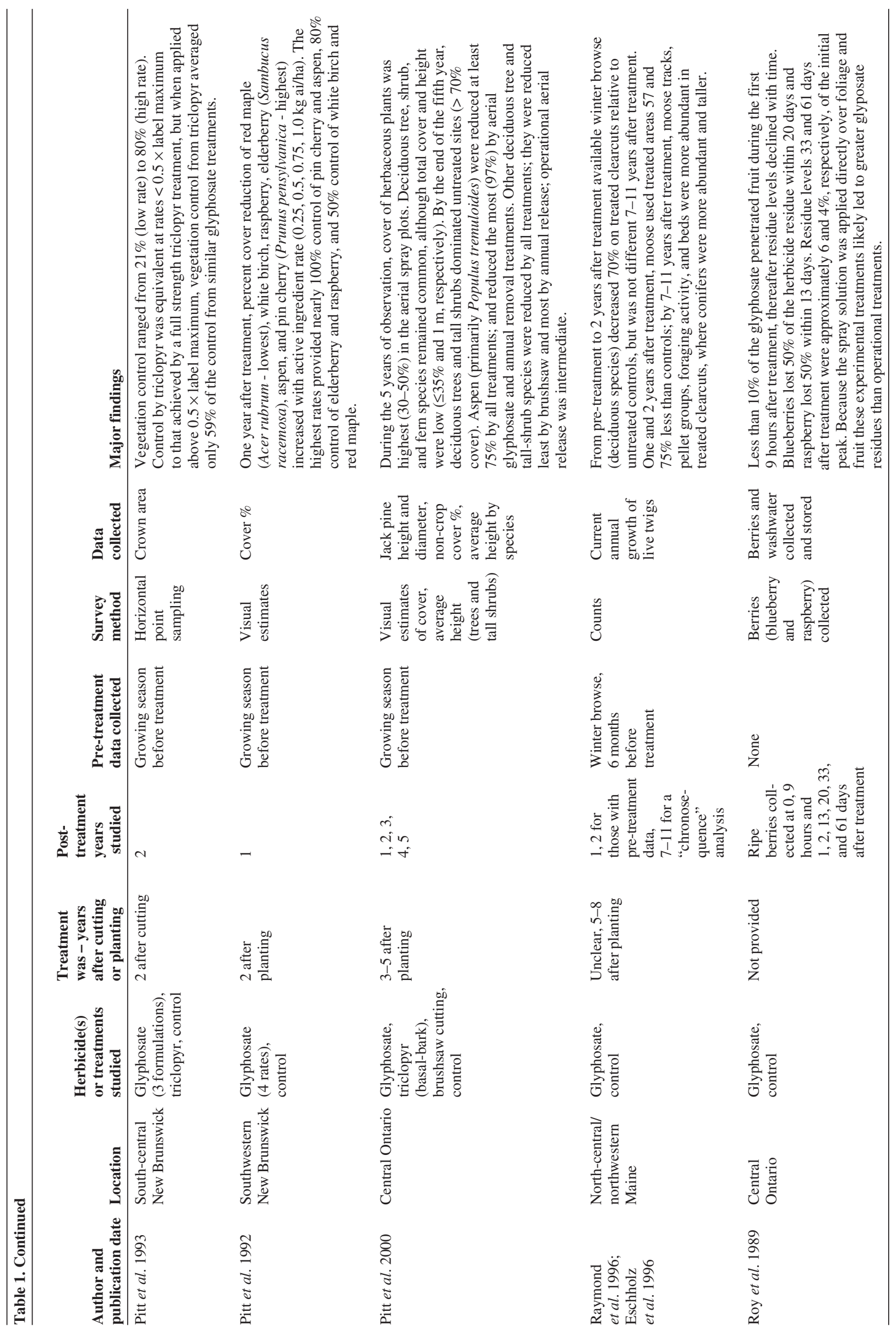




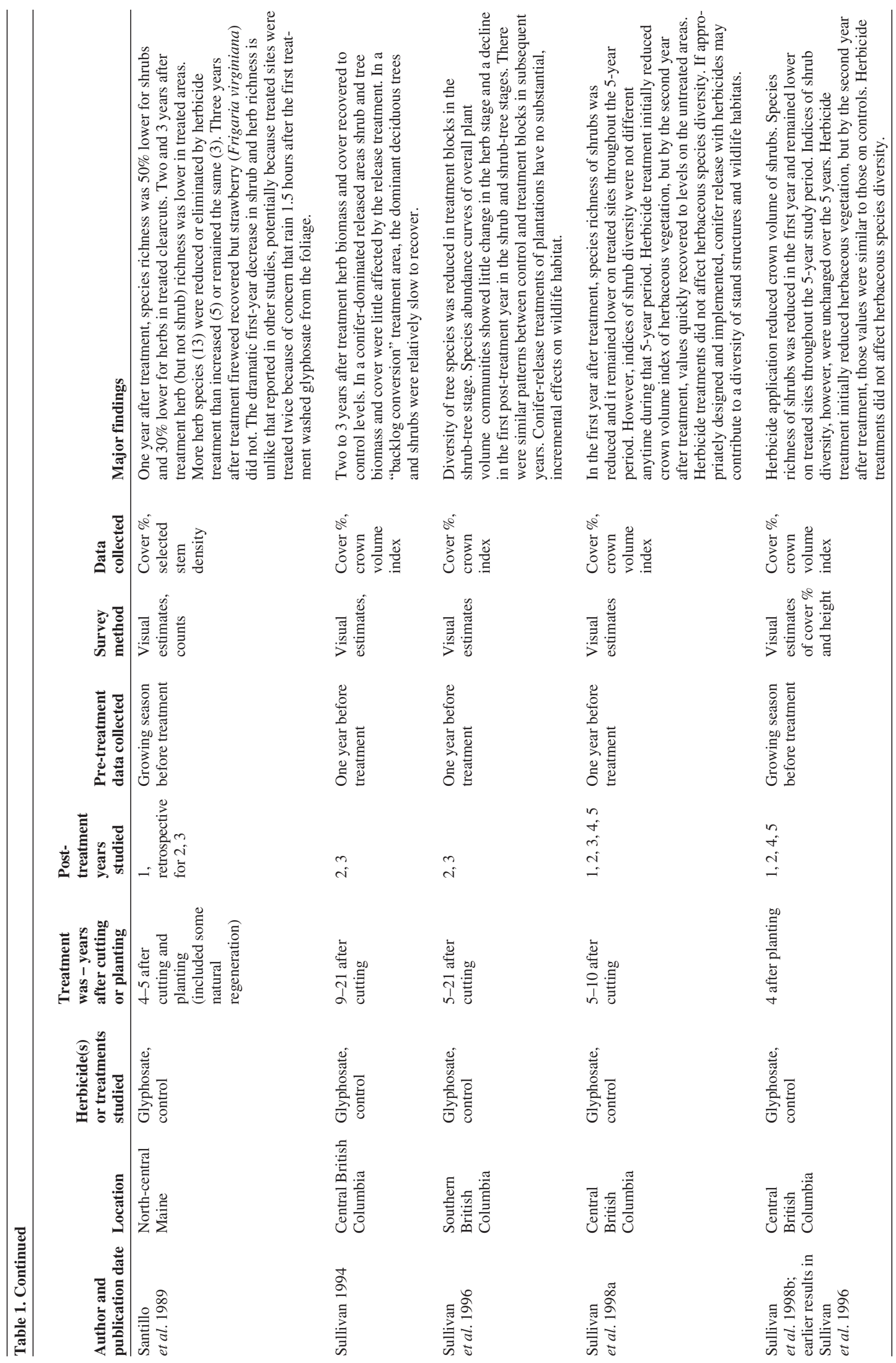




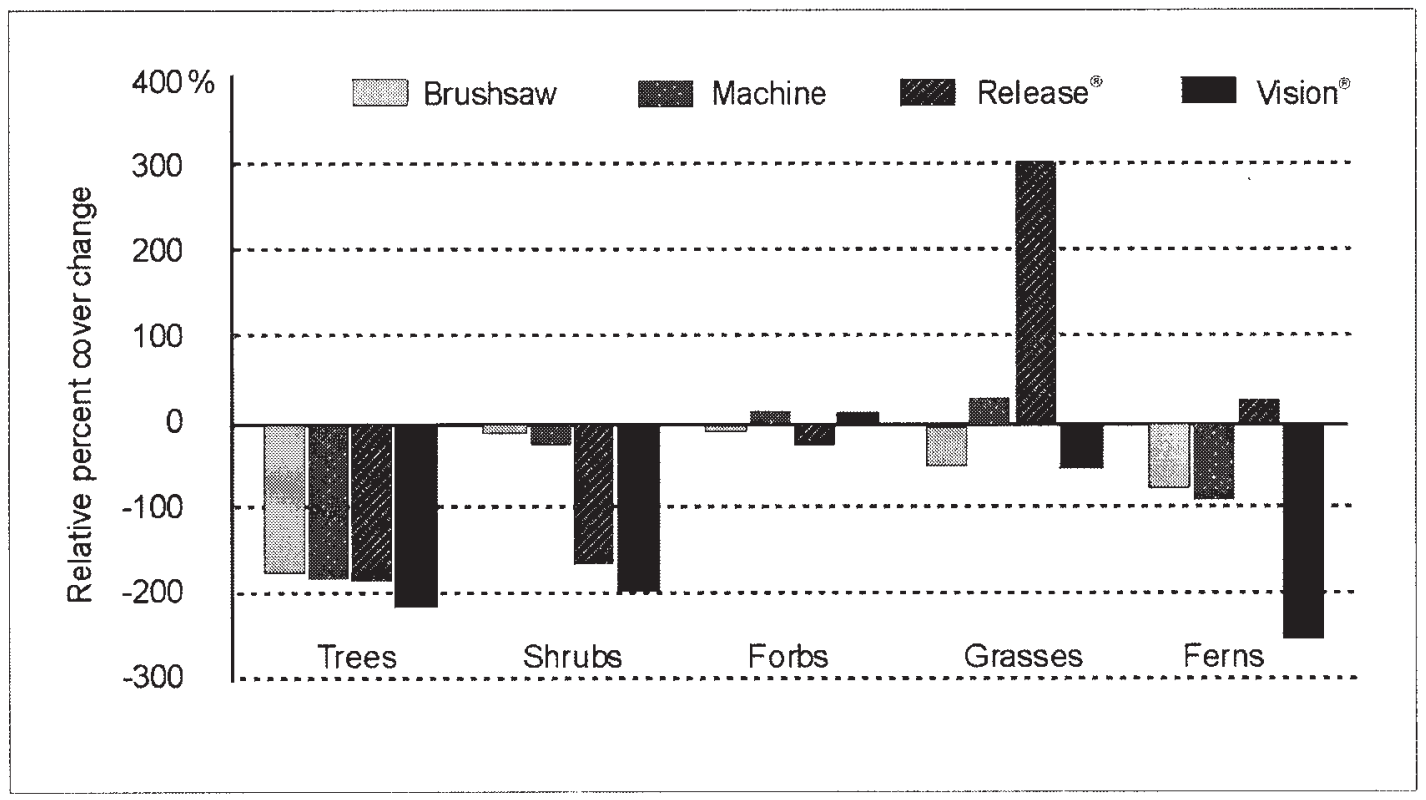

Fig. 1. Relative cover (adjusted for changes on controls) one growing season after treatment, by conifer release treatment type and vegetation group (N=4). Source: Bell et al. 1997.

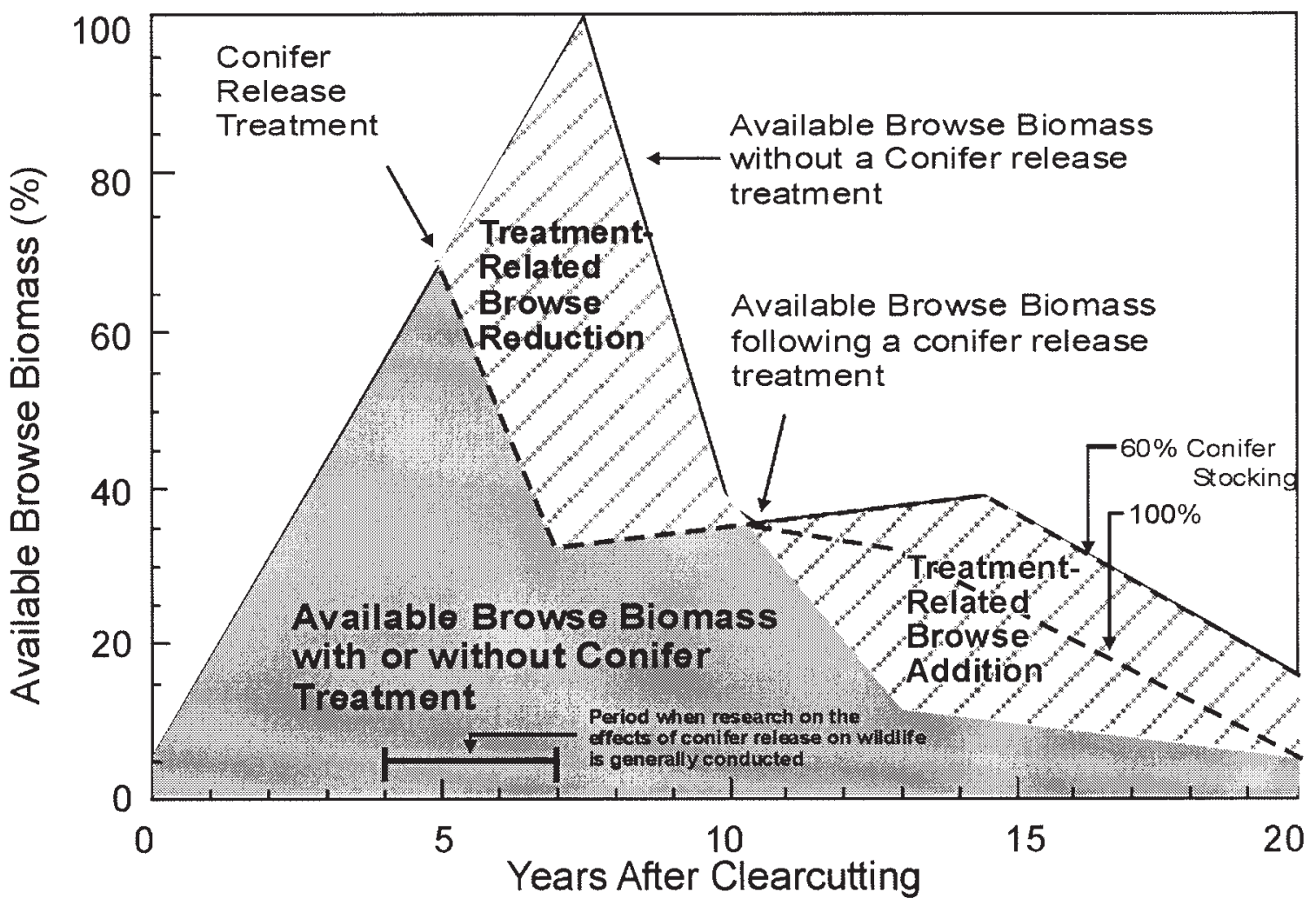

Fig. 2. Projected growth and available browse biomass with and without conifer release with herbicides. Source: Lautenschlager 1993b.

Boateng et al. 2000; Lindgren and Sullivan 2001). Indeed, plant species richness and related diversity indices often remain the same or increase on treated sites, because resident species generally remain and new species invade to occupy newly created niches (Swindel et al. 1984, Lautenschlager and McCormack 1989, Jobidon 1990, Freedman et al. 1993, Horsley 1994, Simard and Heinemann 1996, Lautenschlager et al. 1998, Sullivan et al. 1998a, Boateng et al. 2000, Lindgren and Sullivan 2001). Species are not eliminated because "(1) treatments are not designed to remove all competing vegetation but rather to reduce the level of competition; (2) treated areas often contain 'skips' (unintentionally unsprayed areas); (3) minimum effective volumes 


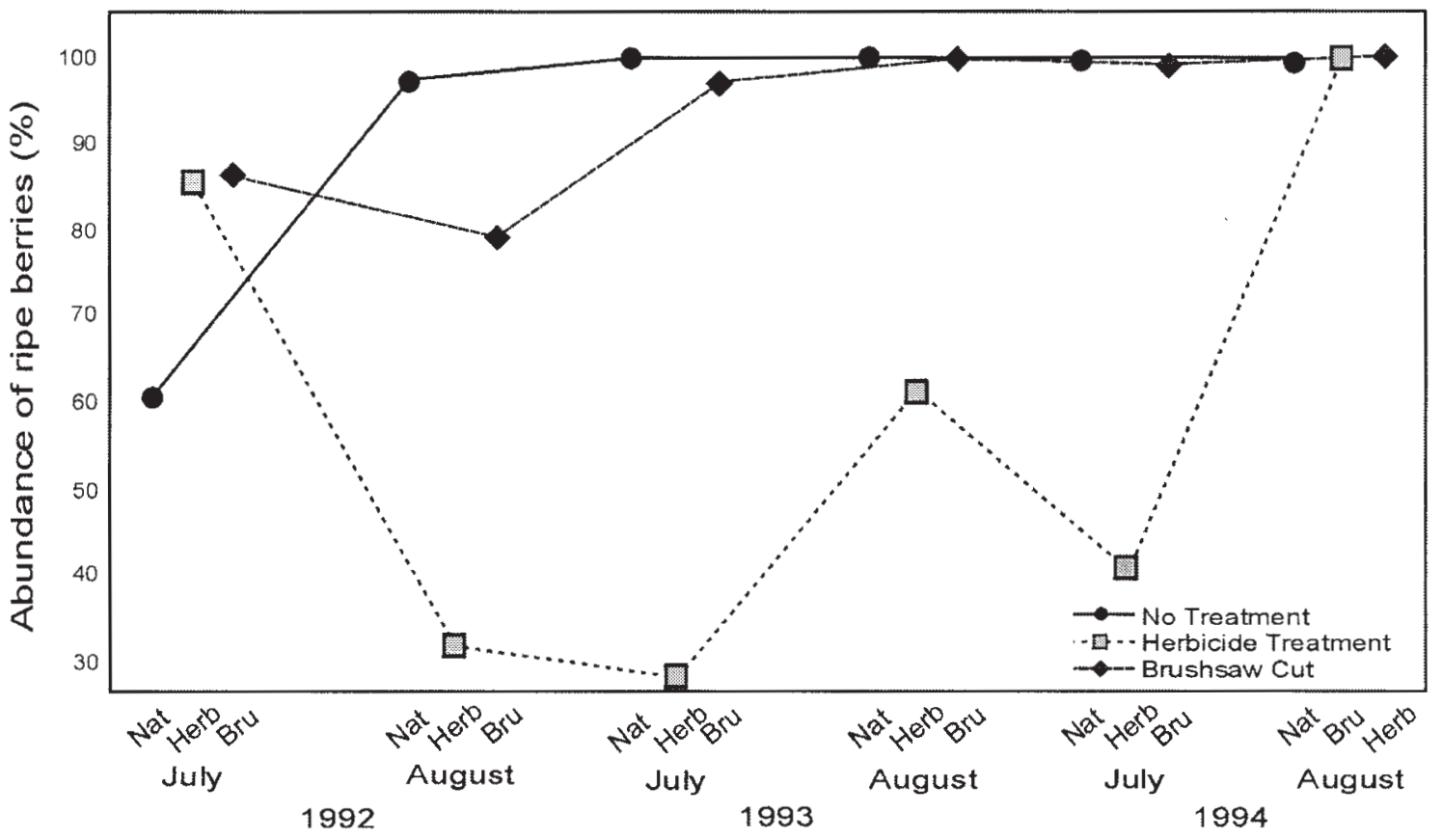

Fig. 3. Effects of no-treatment, herbicide (glyphosate) release, and brushsaw cutting on ripe berry abundance. Source: Gagné et al. 1999.

are applied; (4) low-growing vegetation often remains untreated when it is sheltered by taller vegetation" (Lautenschlager 1993a); and 5) increasingly, ground-based and aerial applications are focused on areas containing the densest competition, providing patch as opposed to broadcast control. That reduction in total control across treated areas will likely result in even fewer biotic differences, relative to controls, than have been found in the past and reported in this paper.

How long, however, do post-treatment vegetation reductions persist, following broadcast treatments? Newton et al. (1989) provided data that allowed Lautenschlager (1993a,b) to model changes in biomass availability of woody deciduous cover (browse) associated with post-clearcutting conifer release treatments (Fig. 2 ). Those data and models indicate that broadcast aerial treatments reduce non-conifer near-ground plant biomass below untreated controls for up to five years after treatment. At that time nearground herbaceous and woody vegetation biomass on treated areas starts to exceed that on untreated controls, and provides more food and cover for some wildlife than vegetation on similar-aged untreated controls. In addition to differences associated with post-treatment successional time, reductions in and the reoccupation of treated areas by non-conifers seem to be linked to both site quality and conifer density (Lautenschlager 1993b).

Site quality influences the speed of recovery and biomass development on treated sites through time. All things being equal, vegetation recovers more quickly on richer than on poorer sites (Lautenschlager 1995). Although we know of no tests of effects of conifer density on browse recovery or availability, successfully released, poorly stocked conifer stands likely produce more non-conifer cover (potential browse) through time than do similar fully stocked stands.

\section{Fruit Production}

Concerns about the potential toxicity of herbicide treated plants that produce fruit used by wildlife and humans have been raised (Roy et al. 1989, Hamilton et al. 1991, Lloyd 1994). In addi- tion, fruit production following treatment has been quantified (Moola et al. 1998, Gagné et al. 1999, Pitt et al. 2000). On richer sites, berry-producing shrubs, such as red raspberry (Rubus idaeus), are commonly the target of competition control (Newton et al. 1987, Roy et al. 1989, Lautenschlager 1990, 1995). As with other species, biomass reductions of fruit-producing species have consistently been recorded, but reductions seem to be short lived (Lautenschlager 1995, Gagné et al. 1999).

Roy et al. (1989) examined uptake and persistence of glyphosate in the fruit of wild blueberry (Vaccinium spp.) and red raspberry and found that, following an experimental treatment, less than $10 \%$ of the glyphosate contacting the fruit adhered to or penetrated that fruit. After the initial peak in the amount of active ingredient recovered from the fruit, herbicide residue levels declined gradually through time. They reported that glyphosate levels in treated fruit remained above the permissible maximum residue level (MRL) of 0.01 ppm established by Health Canada. However, because they removed the overstory that would normally intercept a significant part of any aerial spray solution (Thompson et al. 1997), their experimental treatment likely led to greater residues on fruit than would occur following operational treatments.

In addition, because glyphosate is a herbicide, it would not normally be applied to fruit, and hence MRLs that are established to reflect typical use of pesticides would not be set at all, or at very low levels. Indeed, the MRL of $0.01 \mathrm{ppm}$ cited by Roy et al. (1989) is the default value used by Health Canada to reflect pesticide use that is not expected to result in any residue in a food commodity. In addition, risk assessment is not based on MRLs as suggested by Roy et al. (1989). Rather it is based on a reference dose (RfD), the dose or exposure level that is not considered to be associated with any adverse health effect even with lifetime daily dietary exposure. The RfD for glyphosate, based on information from the United States Environmental Protection Agency, is $2 \mathrm{mg} / \mathrm{kg}$ of body weight. When the highest residue levels reported by Roy et al. (1989) 
are examined relative to a $\mathrm{RfD}$ for a $70 \mathrm{~kg}$ person eating $0.5 \mathrm{~kg}$ of blueberries or raspberries immediately after treatment every day of their life, the associated risk is actually 14 (raspberry) to 35 (blueberry) times lower than the RfD for glyphosate (L. Ritter, Toxicologist, University of Guelph, 2001, personal communication).

Hamilton et al. (1991) examined the effects of glyphosate applications on foliage of plants that produce fruit known to be consumed by grizzly bears (Ursus horribilus) in floodplain ecosystems in British Columbia. They concluded that groundbased foliar applications reduced the foliage of those shrubs by an average of $63 \%$ one year after treatment and influenced fruit availability for at least three years. In an unpublished report, Lloyd (1994) examined longer-term effects of operational aerial glyphosate treatments in north-central British Columbia on a variety of vegetation, including foliage of several fruit-producing species. Although only means are presented, it is clear that cover of fruit producing species varied widely on both the treated and untreated sites studied. However, treated and untreated sites had about the same mean cover percentages of berry-producing foliage seven to nineteen years after treatment. Cover of fruit-producing species in 14-19 year-old treated areas was dominated by Rubus spp., primarily red raspberry, while similar-aged untreated areas had a greater diversity of berryproducing species.

Moola et al. (1998) examined effects of brushsaw cutting, operational, and experimental (annually repeated) conifer release treatments with glyphosate on blueberries ( $V$. angustifolium and $V$. myrtilloides) in regenerating jack pine stands in northwestern Ontario. They reported that "blueberry fruit production was highly variable in time and space, and consequently, these results are difficult to interpret - particularly ... in the single Vision ${ }^{\circledR}$ sprayed plots" (Moola et al. 1998:846). However, they found that following a single operational treatment (aerial) with glyphosate, blueberry production (fresh biomass, primarily of $V$. angustifolium) was reduced 30, 39, and 69\% at two, three, and four years after treatment, respectively. The annually repeated herbicide treatments essentially eliminated blueberry production. However, field foresters seldom use repeated treatments and do not view blueberries as particularly competitive. Thus, areas with extensive blueberry cover are rarely treated unless blueberries are associated with one or more taller competitive species, e.g., trembling aspen (Populus tremuloides), as was the case in this study.

Gagné et al. (1999) examined effects of brushsaw cutting and operational glyphosate treatments on vegetation, including soft mast production [primarily red raspberry but also currant (Ribes spp.), bunchberry (Cornus canadensis), yellow clintonia (Clintonia borealis), and red elder (Sambucus racemosa)] in northeastern Quebec. They found that, when compared with untreated controls, the abundance of ripe berries was reduced 2.5 to 3.0 times in brushsaw-cut and herbicide-treated areas within a month after an August treatment. In July of the following year, ripe berry abundance was 3.8 times less in herbicide-treated plots, than in untreated plots but it had increased in brushsaw-cut plots where it was similar to that in untreated plots. However, by the following month (August) berry abundance in herbicide-treated plots was only 1.6 times less than in untreated plots. Although there was a 2.4 times difference between herbicide-treated and the other treatment types in July during the second year after treatment, by the following month (two years after treatment), all treatments had similar soft mast abundance levels (Fig. 3).

Pitt et al. (2000) examined effects of operational aerial glyphosate release treatments and various ground-based alternatives on low-shrub species in central Ontario. They found that low-shrub [including sweetfern (Comptonia peregrina), blueberry, bush honeysuckle (Diervilla lonicera), and red raspberry] cover was reduced following the operational aerial herbicide treatment. In contrast, low-shrub coverage increased in control areas and in areas where conifer release was achieved via ground-based applications of glyphosate, triclopyr, and brushsaw cutting. Five years after treatment, blueberry cover was lowest $(\sim 2 \%)$ in aerial glyphosate-treated plots, intermediate $(\sim 8 \%)$ in control, basal bark (triclopyr), and mist blower (glyphosate) treated plots, and highest $(\sim 19 \%)$ in brushsaw-treated plots. At the same time, red raspberry recovered most rapidly following the aerial herbicide treatment; reaching $6 \%$ on the operational aerial herbicide-treated plots, but it remained low $(<2 \%)$ on control plots and plots that received ground-based herbicide, and brushsaw-cutting treatments.

\section{Mosses, Lichens, and Fungi}

Few studies have examined the effects of herbicides on mosses, lichens, or fungi. Bell and Newmaster (1998) provided field data documenting the consequences of operational treatments; Newmaster et al. (1999) provided results of a manipulative field experiment; and Boateng et al. (2000) documented effects of simulated broadcast- and spot-herbicide treatments on mosses and lichens.

Bell and Newmaster (1998) found that forest harvesting reduced moss species richness and abundance dramatically. Post-harvest herbicide release treatments further reduced species richness significantly and abundance slightly, but brushsaw cutting did not. Reductions in richness and abundance, however, were no longer statistically different three years after the operational treatments were applied. Boateng et al. (2000) found that moss and lichen richness and diversity were reduced slightly, but not significantly, 10 and 12 years after treatment.

Newmaster et al. (1999) examined moss and lichen abundance and species richness for two years following experimental treatments with herbicide spray solutions that ranged from 0-5.0 $\mathrm{kg}$ active ingredient (a.i.)/ha (glyphosate) and 0-6.7 kg a.i./ha (triclopyr). They reported that moss and lichen abundance and richness were reduced dramatically as the rate of both active ingredients increased. However, the rates chosen were dramatically greater than these plants would experience during operational treatments. Herbicide deposit is site- and application-technology specific; however, only about $75 \%$ of the a.i. applied during an operational treatment is generally recovered from a treatment site [Feng and Thompson (1989); Newton et al. (1990); Thompson et al. $(1992,1997)]$. Therefore, only $12.5 \%$ of the total a.i. applied ( $9 \%$ of the a.i. intended for the site) is generally recovered from $0.5 \mathrm{~m}$ or lower, the stratum where mosses and lichens occur. So, at the rates mosses or lichens actually receive during operational aerial treatments $(\leq 0.2 \mathrm{~kg}$ a.i./ha), the work by Newmaster et al. (1999) shows no, or nearly no, effect at six months, one year, or two years after treatment.

Huston et al. (1998a, b) documented responses of below-ground biotic components to cutting, site preparation and planting, and those treatments followed by conifer release. They found that soil microbial processes and fungal community structure 


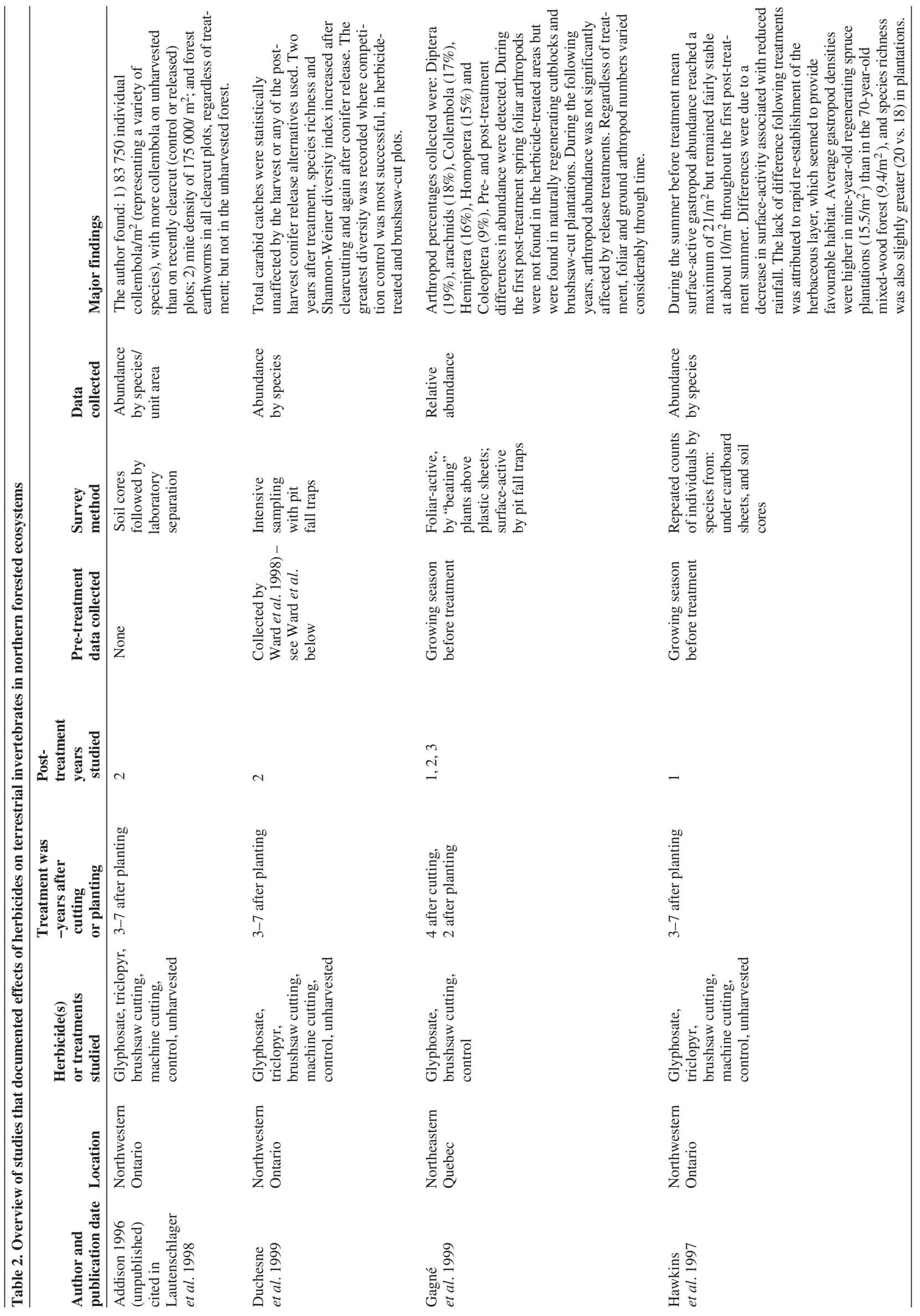




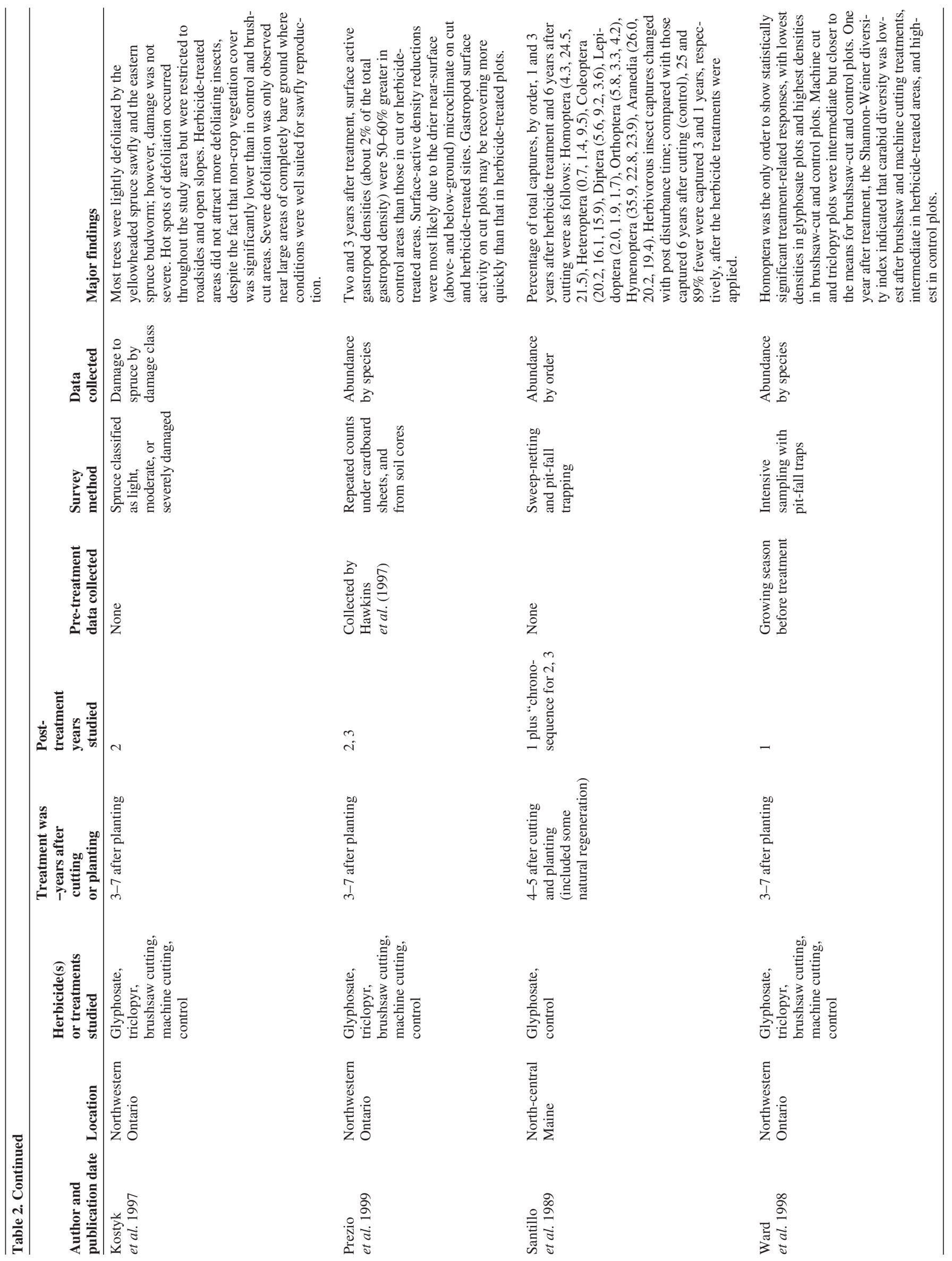




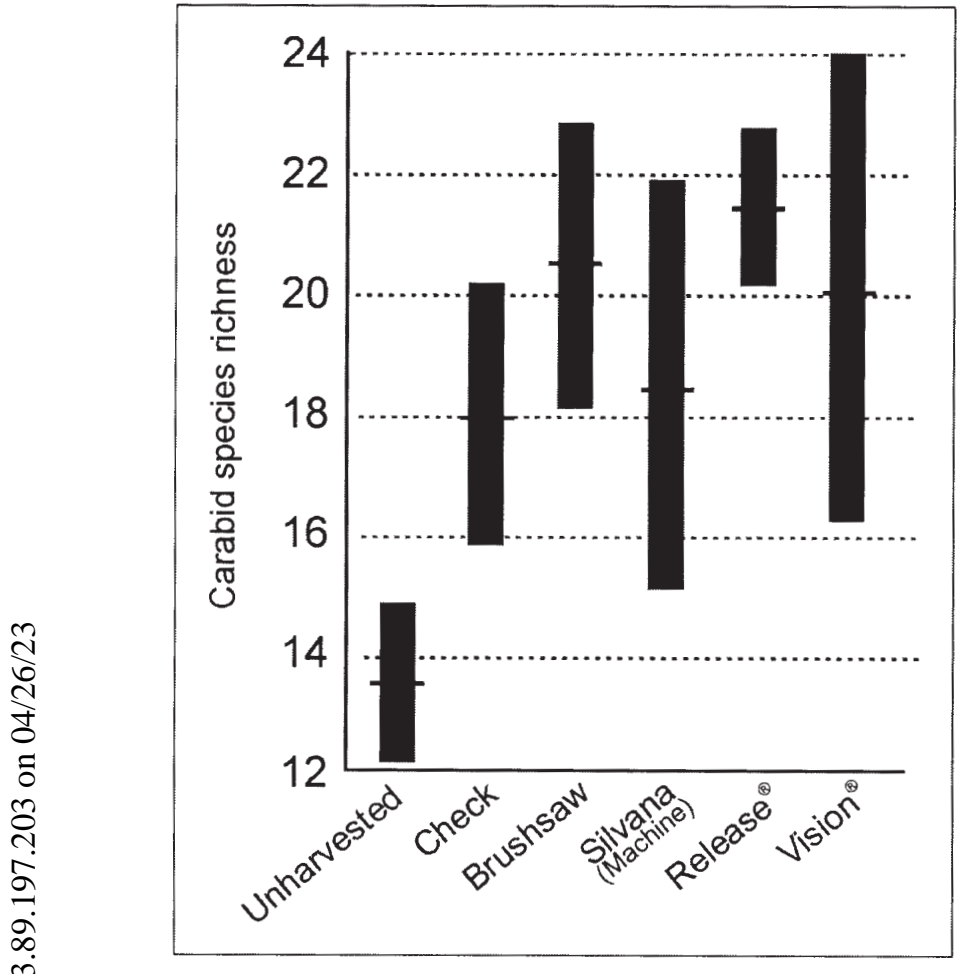

Fig. 4. Mean ( \pm standard deviation, $N=4$ ) carabid species richness two years after conifer release. Source: Duchesne et al. 1999.

(richness, diversity, composition) were similar in unharvested, clearcut, and clearcut then released [herbicide (glyphosate, triclopyr) or brushsaw cut] stands. However, they noted that although total fungal abundance was not changed, isolation frequencies (the abundance measure used) in organic soil of two fungal species, Mortierella vinacea and Paecilomyces carneus, decreased when samples were collected two years after herbicide and brushsaw release treatments.

\section{Terrestrial Invertebrates (Table 2)}

Sullivan and Sullivan (2000) and Mihajlovich (2001) listed 74 studies that, at least in part, include the effects of herbicides containing glyphosate or triclopyr on terrestrial invertebrates. Most of those studies, however, dealt with agricultural treatments or simulation models. Only eight published studies (Santillo et al. 1989, Hawkins et al. 1997, Kostyk et al. 1997, Lautenschlager et al. 1998, Ward et al. 1998, Duchesne et al. 1999, Gagné et al. 1999, and Prezio et al. 1999) are useful for drawing conclusions about effects of conifer release on terrestrial invertebrates in managed northern forest ecosystems. Results from the Fallingsnow Ecosystem Project in northwestern Ontario (Lautenschlager $e t$ al. 1997a, 1998) are particularly useful because that project documented effects on most terrestrial ecosystem components, including: below-ground, surface-active, and selected foliage-dependent invertebrates to conifer release alternatives. Papers by Hawkins et al. 1997, Kostyk et al. 1997, Ward et al. 1998, and Duchesne et al. 1999, are all based on work conducted at Fallingsnow.

Addison (1996) documented soil fauna abundance at Fallingsnow by examining soil samples collected two years after treatments were applied. She found 83750 individual collem$\mathrm{bola} / \mathrm{m}^{2}$ (representing a variety of species), more collembola in unharvested than in recently clearcut (both control and
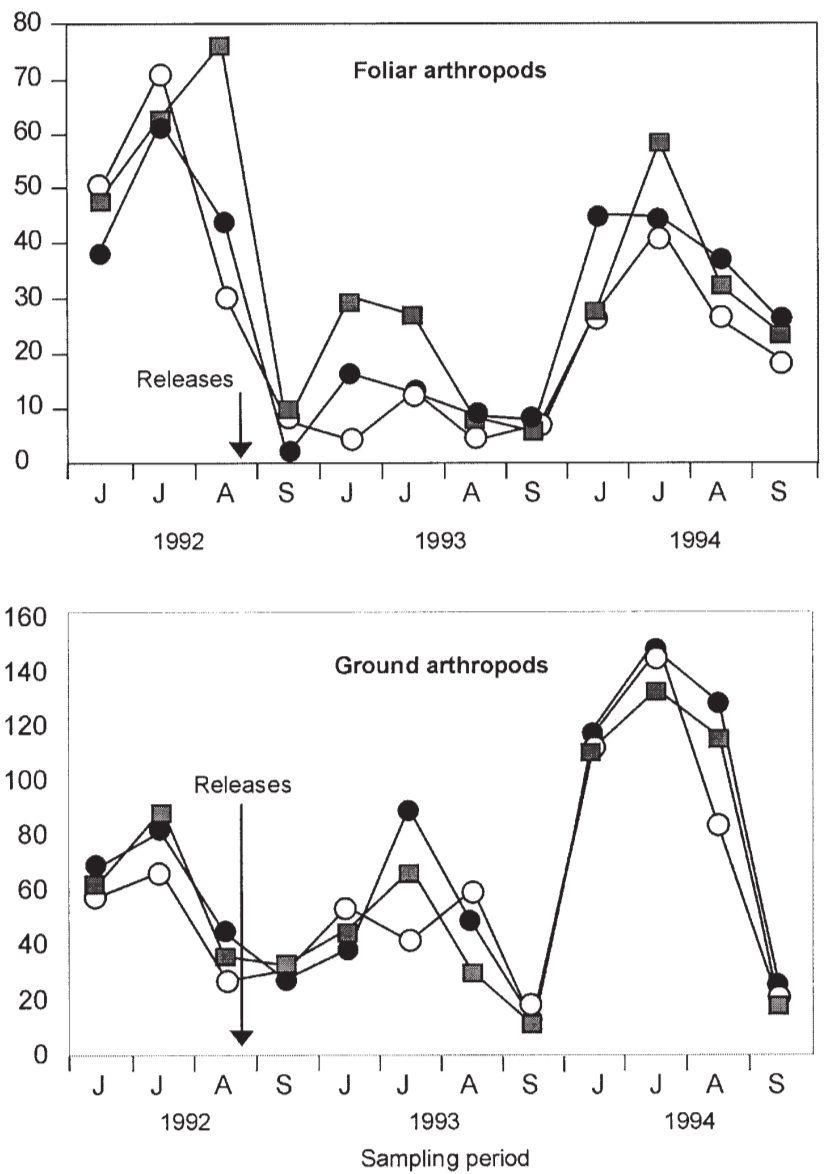

Fig. 5. Relative abundance of foliage and ground arthropods in naturally regenerating cutblocks $(\square$, herbicide- (glyphosate) treated plantations $(\bigcirc$ ), and brushsaw-cut plantations $(\bigcirc)$ by time period. Source Gagné et al. 1999.

released - regardless of treatment type) plots, and mite density of 175000 individuals $/ \mathrm{m}^{2}$ in clearcut control and released plots. Forest earthworms were found in all clearcut plots, regardless of the alternative release treatment applied, but earthworms were not found in the unharvested forest plots.

Santillo et al. (1989) provided experimental and retrospective information about surface-active and near-ground insect responses one and three years after operational glyphosate treatments. They found increasing abundance of insects through postdisturbance time with 446 captures one year after herbicide treatment, 644 three years after treatment, and 900 on the untreated control (an area harvested six years previously).

Ward et al. (1998) examined treated plots before and the year after treatments and concluded that conifer release [using herbicides (glyphosate and triclopyr), brushsaw, and machine cutting treatments] had little effect on most insect groups during the first year after treatment. Homoptera was the only order affected by any of the conifer release alternatives studied, with lowest densities in the glyphosate plots and highest densities in the brushsaw-cut and control plots.

Duchesne et al. (1999), used pre- and one-year post-treatment data collected by Ward et al. (1998) and re-examined those plots plus plots in the adjacent unharvested forests, two years after treatment. They found total Carabid catches were not sig- 


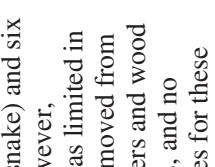

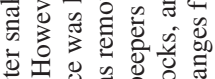

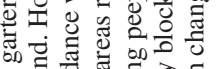

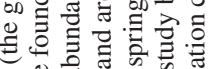

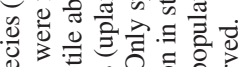

至

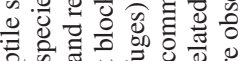

政专

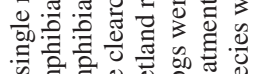

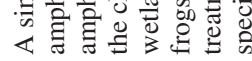

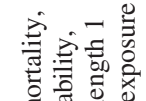

离

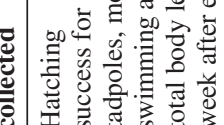

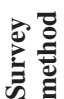

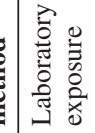

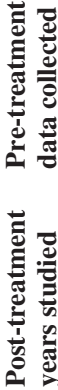

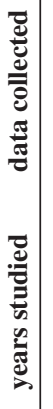

zั๊

结늘

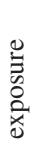

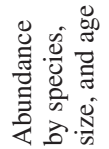

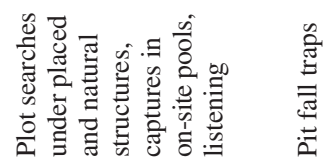

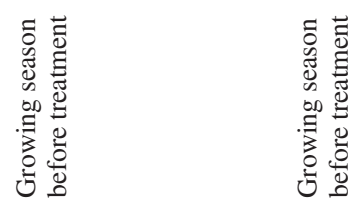

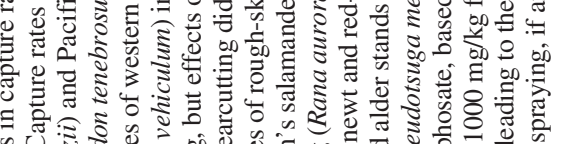

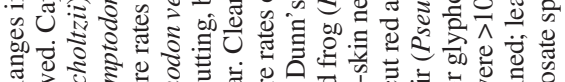

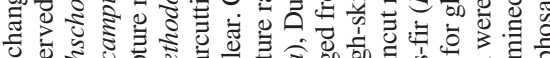

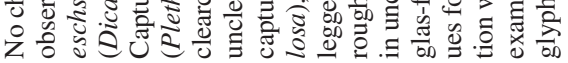

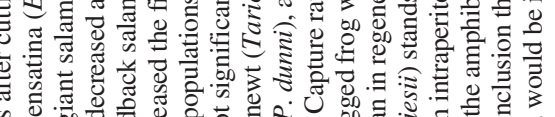

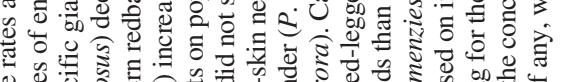

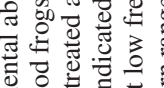

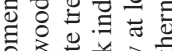

응

을 을

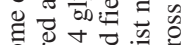

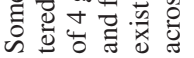

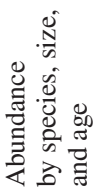

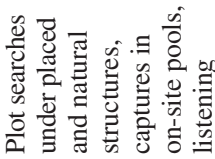

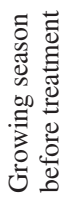

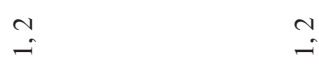

$\stackrel{-1}{-}$

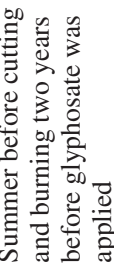

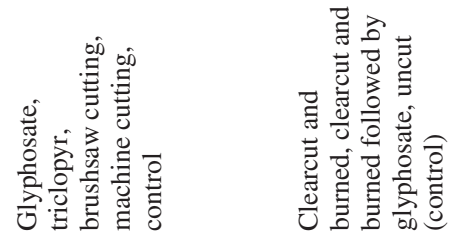

章

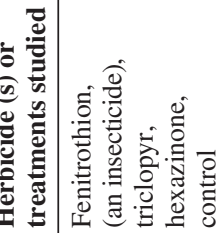

竞

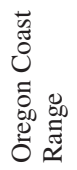

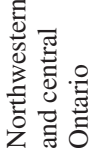

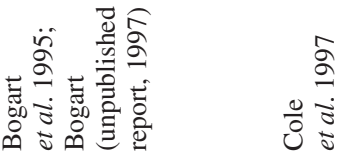

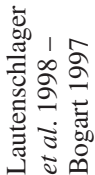


nificantly affected by timber harvesting or the post-harvest conifer release alternatives used. Indeed, by two years after treatment, species richness, and diversity indices (Shannon-Weiner and Simpson) were consistently higher (although not always statistically significantly so) on clearcut plots and higher still on released plots. The greatest diversity was recorded where competition control was most successful: in herbicide-treated and brushsaw-cut plots (Fig. 4).

Gagné et al. (1999) had pre-treatment and arthropod response data for two years after treatment. They found that foliar and surface-active arthropod abundance decreased one year after treatment (clearcut followed by glyphosate or brushsaw). During the second year after treatment, abundance of foliar and surface-active arthropods and arachnids varied considerably throughout the study area, but was statistically unaffected by release (Fig. 5). However, as would be expected, foliar arthropods were less abundant (although not statistically so) during that time in herbicide-treated sites than in older naturally regenerated sites and brushsaw-cut plantations.

Kostyk et al. (1997) and Woodcock (1997) examined the responses of defoliating insects to several conifer release alternatives. Kostyk et al. (1997) found that many of the planted conifers, examined two years after treatment, were lightly defoliated by the yellowheaded spruce sawfly (Pikonema alaskensis) and eastern spruce budworm (Choristoneura fumiferana). However, herbicide-treated areas had no more insects or related damage than did brushsaw-cut or control areas, despite the fact that non-crop vegetation cover was significantly lower in herbicide-treated areas.

While documenting songbird responses to the same alternative treatments, Woodcock (1997) and Woodcock et al. (1997) documented abundance of defoliating insects in the regenerating spruce. Two years after release treatments, spruce budworm biomass $(\mathrm{g} / \mathrm{tree})$ was greater in spruce trees growing on control plots than in brushsaw-cut or herbicide-treated plots. However, budworm populations were similar among treatment types by three years after release (Lautenschlager et al. 1998).

Hawkins et al. (1997), Prezio (1997) and Prezio et al. (1999) produced the first publications examining effects of herbicides on terrestrial gastropods. Hawkins et al. (1997) collected 21 gastropod species (two slug and 19 snail) and reported that, during the first growing season after release treatments, neither density nor species richness was affected by the alternatives tested. In addition, surface-active densities in clearcuts (nine to sixteen $/ \mathrm{m}^{2}$ ) were consistently greater than those in adjacent unharvested forests (seven to nine $/ \mathrm{m}^{2}$ ) (Hawkins et al. 1997), a trend that continued through the next two years (Prezio 1997). Prezio et al. (1999) found that by three years after release, densities of surface-active gastropods were lower on herbicide-treated than on control plots. However, three and four years after treatment, soil-dwelling gastropod abundance was similar in soils collected from herbicide-treated $\left(377 / \mathrm{m}^{2}\right)$ and control plots $\left(258 / \mathrm{m}^{2}\right)$ (Prezio 1997).

\section{Amphibians and Reptiles (Table 3)}

Published work examining effects of conifer release with herbicides on amphibians and reptiles is limited to laboratory studies with frog embryos and tadpoles (Berrill et al. 1994), studies in the Oregon Coast Range (Cole et al. 1997), and field and laboratory work in Ontario (Bogart et al. 1995, Lautenschlager et al. 1998).
In the laboratory, Berrill et al. (1994) examined responses of embryos and tadpoles of the leopard frog (Rana pipiens), green frog (Rana clamitans), and bullfrog (Rana catesbeiana) to fenitrothion (an insecticide) and two active ingredients (hexazinone, triclopyr) found in herbicide products. Hexazinone had no effect on embryos or tadpoles even at exposure levels dramatically higher than amphibians would experience in the wild. However, newly hatched tadpoles of all species were very sensitive to 2.4 and $4.8 \mathrm{ppm}$ triclopyr; following exposure they either died or were paralyzed. Tadpole species sensitivity to triclopyr was bullfrog $>$ green frog $>$ leopard frog. However, because conifer release treatments in northern forest ecosystems occur during late summer, areas with water are not treated, and triclopyr breaks down relatively quickly, tadpoles in the wild are unlikely to be exposed to triclopyr.

In the Oregon Coast Range, Cole et al. (1997) examined effects of cutting, burning, and both treatments followed by a fall glyphosate application (1.3 kg a.i./ha). They also determined $\mathrm{LD}_{50}$ values for common amphibians [ensatina (Ensatina eschscholtzii), western red-back salamander (Plethodon vehiculum), Pacific giant salamander (Dicamptodon tenebrosus), rough-skin newt (Taricha granulosa), and tailed frog (Ascaphus truei)]. Intraperitoneal-injection $\mathrm{LD}_{50}$ values were $>1000$ $\mathrm{mg} / \mathrm{kg}$ for those species, and based on a dose acquisition model, oral and dermal absorption of glyphosate after field application was predicted not to exceed $1.2 \mathrm{mg} / \mathrm{kg}$ for any of these species. Therefore, the authors concluded that effects of conifer release, if any, would be indirect (habitat changes) rather than direct (toxic). In addition, capture rates suggested no effects of a glyphosate application on amphibian abundance or species richness.

In northwestern Ontario, Bogart et al. (1995) found only a single reptile species, the relatively common garter snake (Thamnophis sirtalis), and six amphibian species in studied blocks. During the growing season following conifer release treatments, 11 garter snakes from study blocks and 16 from adjacent areas were captured, and their reproductive conditions noted. Six $(55 \%)$ of the study block snakes were gravid, while only one $(6 \%)$ of the snakes from adjacent areas was gravid. Snakes have extensive home ranges; thus, they commonly moved in and out of study blocks as well as among treatment plots within blocks. However, even this small sample suggests that habitat quality for snakes in areas treated with herbicides was not reduced and may have increased following treatment (Bogart et al. 1995).

Amphibian abundance in the study by Bogart et al. (1995) was limited because experimental blocks were upland areas removed from extensive wetland refuges. Although bluespotted salamander (Ambystoma laterala), American toad (Bufo americanus), spring peeper (Pseudacris crucifer), striped chorus frog (Pseudacris triseriata), tetraploid grey treefrog (Hyla versicolor), and wood frog (Rana sylvatica) were found in treatment blocks, only spring peeper and wood frog were common. No treatment-related population changes for these species were observed during the first two years after treatment (Lautenschlager et al. 1998). However, occasional developmental abnormalities were observed among wood frogs collected from one glyphosate-treated plot. Further work found that those abnormalities occurred regularly, although infrequently, in this species across its northern range (Lautenschlager et al. 1998). 


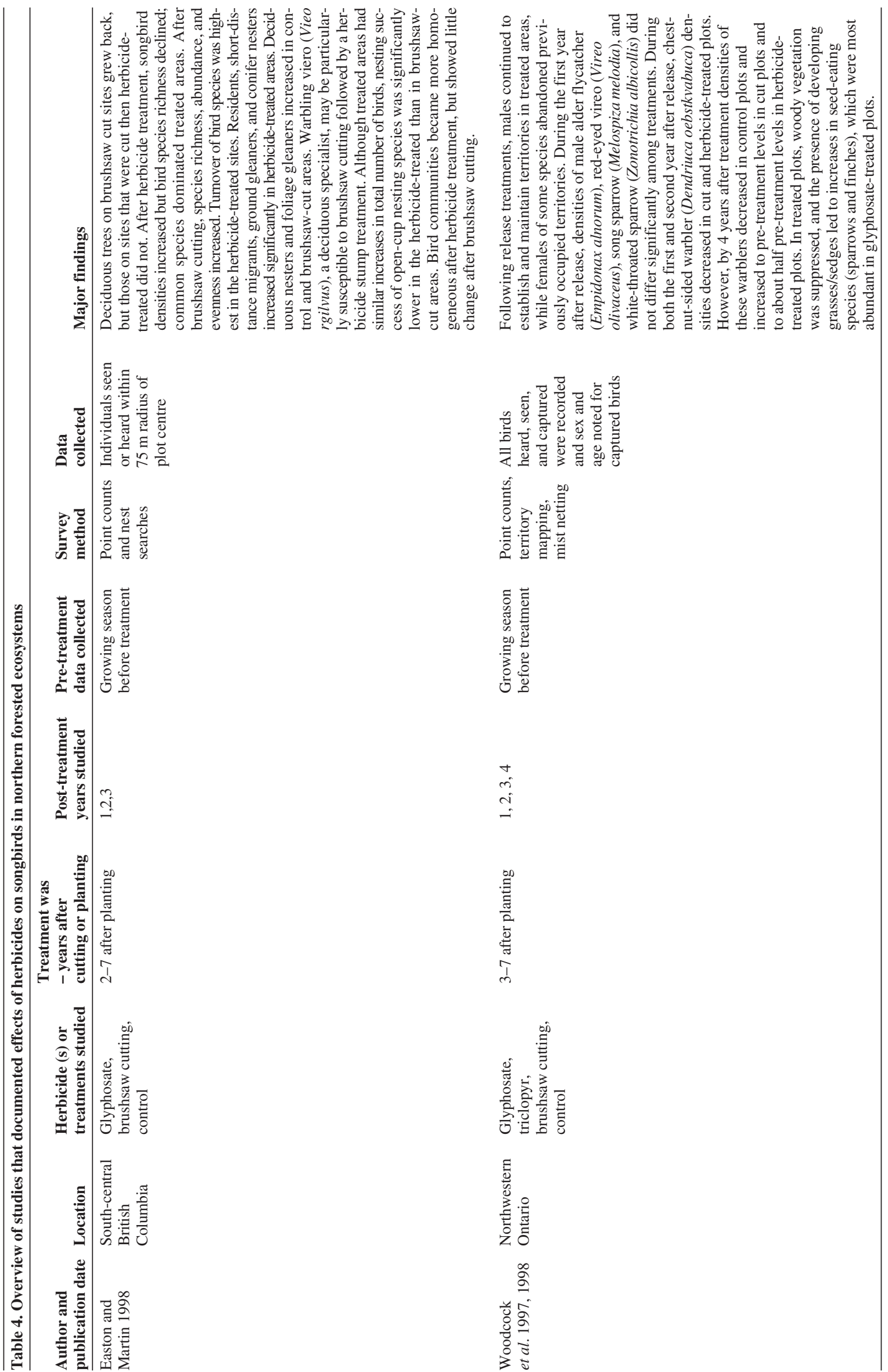




\section{Songbirds (Table 4)}

With the exception of work by Woodcock et al. (1997, 1998) and Easton and Martin (1998), little new data have been added to the literature documenting effects of herbicides used for forest management on songbird populations. Unlike much previous short-term research, Woodcock et al. (1998) examined bird populations pre-treatment and for four years after treating 3.3-12.5-ha plots on four replicated blocks via brushcutting (brushsaws, large cutting machine), two herbicides (glyphosate, triclopyr), and nothing (control). Spot mapping, territory mapping, and mist netting were used to document effects by gender as well as reproductive output.

Woodcock et al. (1997) recorded 20 to 38 (block-dependent) species, but only 11 species were common enough for statistical comparisons. Results, based on territory mapping, indicated that densities of most, including alder flycatcher (Empidonax alnorum), red-eyed vireo (Vireo olivaceus), song sparrow (Melospiza melodia), and white-throated sparrow (Zonotrichia albicollis) did not differ among treatments during the first year after release. However, chestnut-sided warbler (Dendroica pensylvanica) densities varied among treatments during both the first and second year after treatment (higher in control plots and lower in treated plots; lowest in brushsawcut plots). By four years after treatment, chestnut-sided warbler numbers were decreasing in control plots (likely because habitat quality decreased as succession proceeded), were increasing towards pre-treatment levels in cut (brushsaw, machine) plots, and were about one-half pre-treatment levels in herbicide-treated plots (Lautenschlager et al. 1998).

In general, during the first few years after treatment, songbird species dependent on hardwood foliage (parulid warblers, vireos, and thrushes) were more common in control plots than in any of the treated plots. In treated plots, woody vegetation was suppressed, and in glyphosate-, and especially triclopyr-treated plots, the developing grasses/sedges that increased in abundance soon after treatment provided foods for seed-eating species (sparrows and finches) (Woodcock et al. 1997). The presence of a significantly higher proportion of high shrubs inside territories $(\sim 20-37 \%)$, compared with outside $(\sim 15 \%)$, seemed to have been the factor influencing area use by alder flycatcher, chestnut-sided warbler, mourning warbler (Oporornis philadelphia), Nashville warbler (Vermivora ruficapilla), red-eyed vireo, and veery (Catharus fuscescens) (Woodcock et al. 1998). These species were reduced by treatments that removed high shrubs while early successional and more generalist species, white-throated sparrow, Lincoln's sparrow (Melospiza lincolnii), and song sparrow, increased following those treatments.

During their three-year study, Easton and Martin (1998) found that deciduous trees grew back on brushsaw-cut sites, but not on cut-stump (glyphosate-treated) sites. After the glyphosate treatment, songbird species richness declined, while abundance of common species, residents, short-distance migrants, ground gleaners, and conifer nesters increased significantly. Songbird species richness, abundance, and evenness also increased after brushsaw cutting. Turnover of songbird species was highest on the glyphosate-treated sites. Deciduous nesters and foliage gleaners increased in control and brushsaw-cut areas. Easton and Martin (1998) observed that warbling vireo (Viero gilvus), a deciduous specialist, seemed particularly susceptible when cut stumps were treated with glyphosate. Although increases in the total num- ber of birds were similar in brushsaw-cut and herbicide-treated areas, nesting success of open-cup-nesting species was significantly lower in the herbicide-treated than in brushsaw-cut areas. Bird community composition became more homogeneous after conifers were released by treating cut stems with glyphosate, while it changed little following brushsaw cutting.

\section{Small Mammals (Table 5)}

Studies documenting responses of small mammals to forest herbicide treatments have been conducted throughout the boreal and boreal mixedwood forests of northern North America (Sullivan and Sullivan 2000, Mihajlovich 2001). Lautenschlager et al. (1995), working in a regenerating jack pine forest in northwestern Ontario, found that red-backed vole (Clethrionomys gapperi) numbers were reduced for one year following brushsaw cutting and two years following an operational glyphosate treatment. Deer mouse populations seemed relatively unaffected by those treatments, while the least chipmunk (Tamias minimus), which at first was unaffected, became more common two years after the initial herbicide treatment on plots treated annually with glyphosate. Abundance of the eastern chipmunk (Tamias striatus), however, was reduced by all treatments.

In a different study in northwestern Ontario, Lautenschlager et al. (1997b) reported that abundance of most species occupying regenerating spruce stands was not reduced by any of the operational herbicide or cutting alternatives examined. During the first year after the treatments were applied, however, redbacked vole abundance was highest in control and lowest in herbicide-treated (glyphosate and triclopyr) plots. During the second year after treatment, their abundance on control and herbicide-treated plots was similar. Throughout the study, red-backed vole populations were consistently larger in adjacent unharvested forests (20/ha) than in recent cutovers, regardless of the release treatment used. In these regenerating forest plots, voles were most abundant in untreated control (13/ha), less abundant in brushsaw cut (10/ha) plots, and least abundant in herbicidetreated (6/ha) plots.

In south-central British Columbia, Runciman and Sullivan (1996) found no significant effects of brushsaw cutting or glyphosate cut-stump application on populations of deer mouse, yellow-pine chipmunk (Tamias amoenus), red-backed vole, or long-tailed vole (Microtus longicaudus). In a different British Columbia study, Sullivan and Boateng (1996) found that after treatment (broadcast burning or glyphosate) deer mouse populations were reduced for one to two months in the coastal study area, but those in the interior study area were unaffected. Meadow voles (Microtus pennsylvanicus) disappeared from burned blocks in the interior area, but Oregon voles (Microtus oregoni) persisted in the burned block in the coastal area. Red-backed vole abundance was reduced in both areas, while chipmunks (Eutamias townsendii, E. amoenus) seemed unaffected by either treatment. Neither burning nor glyphosate treatment affected species diversity of the small mammal communities studied. The authors concluded that small mammal abundance was likely affected more by broadcast burning than by herbicide treatment.

In coastal British Columbia, Sullivan et al. (1997) examined two areas sprayed with glyphosate in June and September. They reported that average deer mouse abundance was reduced during the remainder of the growing season following the 


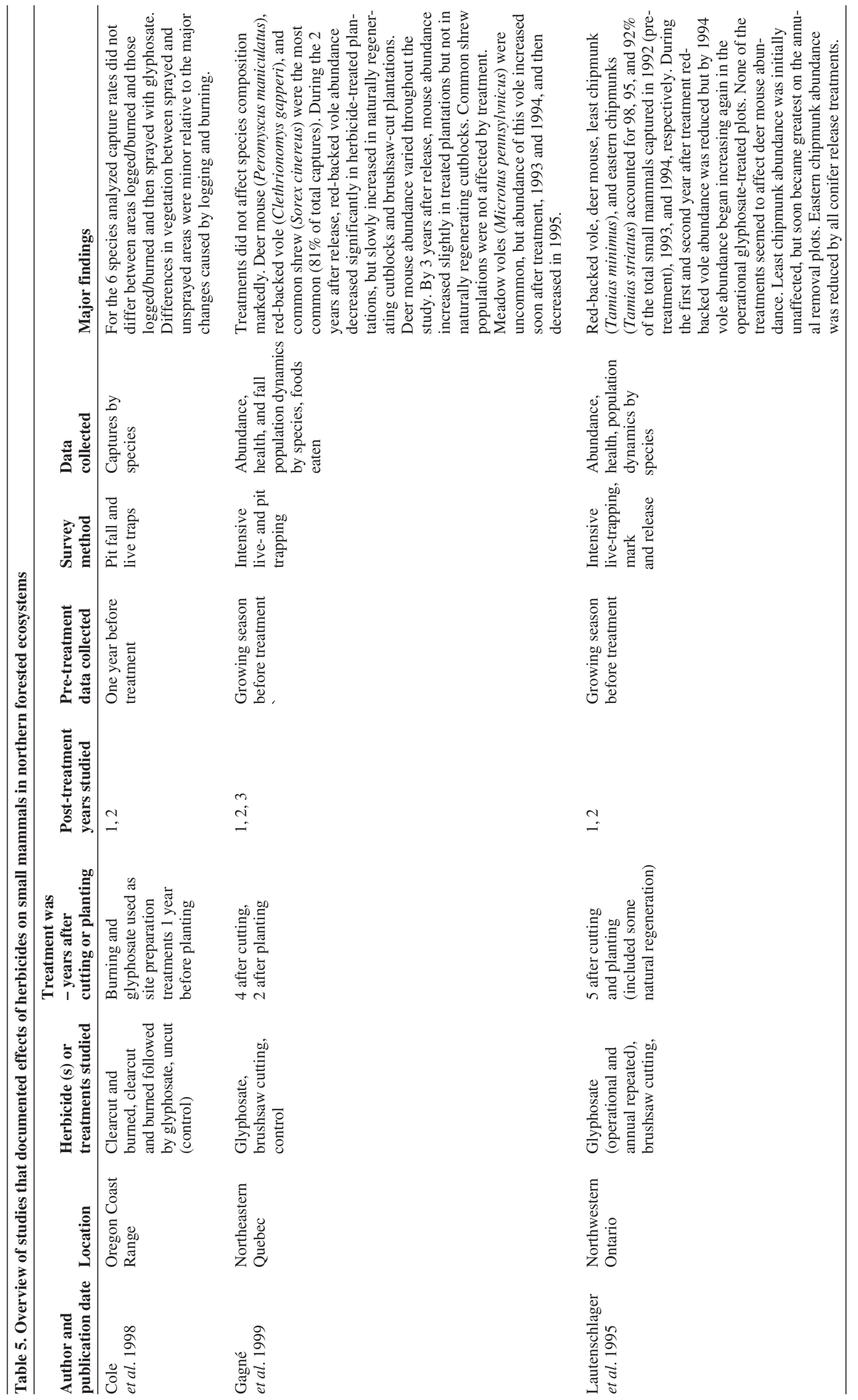




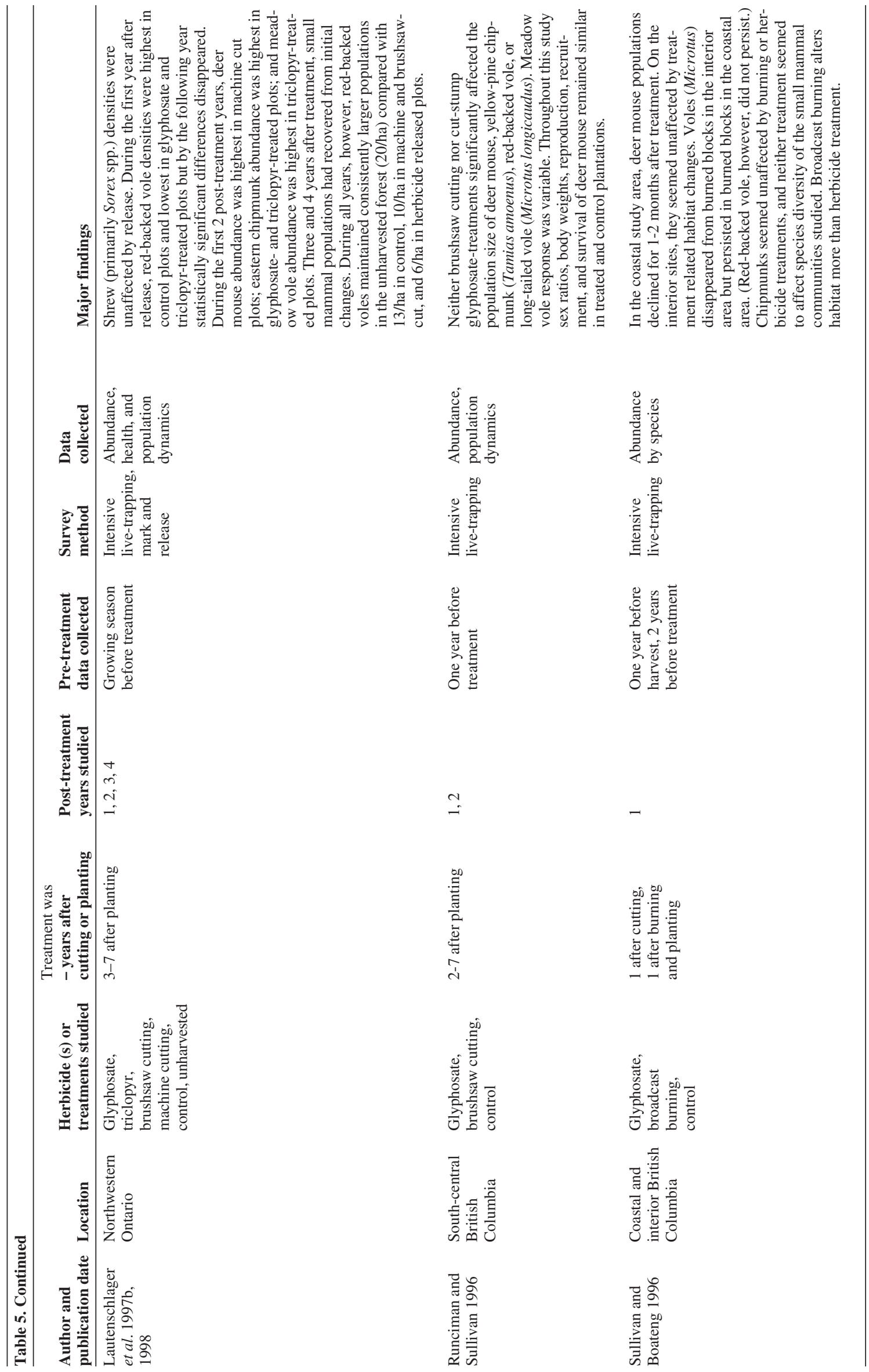




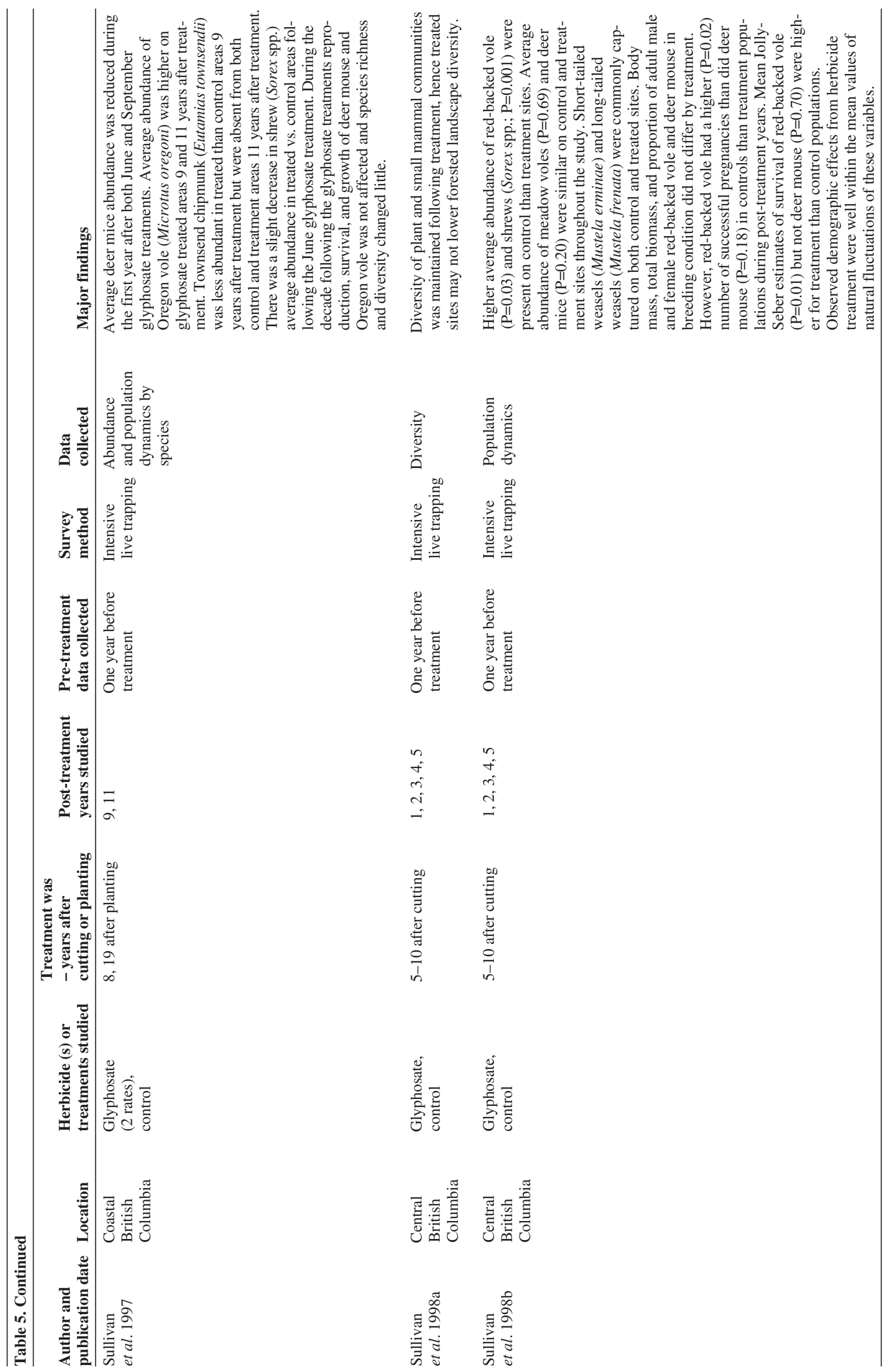


June treatment, and during the following year's growing season after the September treatment. When compared to untreated areas, average Oregon vole abundance was higher in the glyphosate-treated blocks both nine and 11 years after treatment. Townsend chipmunk was less abundant in treatment than control areas nine years after treatment, but was absent from both control and treatment areas 11 years after treatment. Average shrew (Sorex spp.) abundance decreased slightly during the year after the September glyphosate treatment but not the June treatment; by nine and 11 years after treatment, shrew numbers were as great or greater on treated than control areas. During the decade following treatment, glyphosate did not adversely affect reproduction, survival, or growth of deer mice and Oregon voles in coastal forests, and species richness and diversity changed little.

In a study in sub-boreal spruce forests Sullivan et al. (1998a) reported that a single glyphosate treatment generally did not lower small mammal diversity in a forested landscape, but Sullivan et al. (1998b) reported that a single treatment reduced abundance of shrews and red-backed voles, while meadow vole and deer mouse populations were unaffected. Although body mass, total biomass (all species), and the proportion of adults in breeding condition did not differ between control and glyphosate-treated areas, female red-backed voles were gravid in control plots more often than in glyphosate-treated plots (Sullivan et al. 1998b). Weasels (Mustela spp.) were commonly captured in both glyphosate-treated and control plots, suggesting that populations of these carnivores were unaffected by a glyphosate treatment.

Sullivan et al. (1998c) reported average abundance of montane vole (Microtus montanus) declined 53\% to $73 \%$ in treatment compared to control blocks after glyphosate broadcast and strip-treatments were applied to apple orchards. However, deer mouse and northwestern chipmunk populations were either unaffected or increased significantly following these treatments. Interestingly, this compensatory response - fewer voles but more mice and chipmunks - resulted in orchards having similar total small mammal biomass in treated and control areas. Compensatory response has not been discussed by other authors, but it also may occur in other habitats including forests.

Sullivan et al. (1998b) assessed the biological significance of variations in red-backed vole and shrew populations between control and treated areas. The mean changes in abundance and 95\% confidence intervals were considerably smaller for the control/treatment comparison than for annual changes in control populations. Gagné et al. (1999) also found that a glyphosate treatment did not affect small mammal species composition markedly. However, during three years after treatment, red-backed vole numbers decreased in herbicide-treated plots but increased in plots located in naturally regenerated and brushsaw-cut plantations. In a three-year study, Cole et al. (1998) found that applying glyphosate after cutting and burning did not affect capture rates of the common small mammals, including shrews. Small mammal responses to cutting and burning depended on species-specific habitat preferences.

In a minimally replicated, partially retrospective study, Santillo et al. (1989) reported that for three years after treatment, insectivores (primarily the common shrew) were less abundant on glyphosate-treated than control plots. Sullivan et al. (1998b) and Gagné et al. (1999) also found fewer shrews (S. monticolus 
and $S$. cinereus) in glyphosate treated regenerating forest habitats. However, such differences were not observed when shrews were caught both before, and for two years after a variety of conifer release alternatives were applied in regenerating spruce plantations (Lautenschlager et al. 1997b) or in Douglasfir plantations (Sullivan et al. 1997). Although results from these and previous studies differ, it seems that shrew abundance sometimes decreases slightly following conifer release treatments. Those reductions are likely caused by cover reductions, associated microclimate changes (increased near-ground temperatures and decreased relative humidity) (Reynolds et al. 1997), and/or changes in available food (Gagné et al. 1999).

Studies reviewed previously (Lautenschlager 1993a) have consistently found increases in mouse and chipmunk (except eastern chipmunks) abundance and decreases in red-backed vole numbers for as long as two years after treatment. By the third year after treatment, most populations in herbicide-treated plantations have recovered. Complete recovery seems to occur more quickly on richer than on poorer sites (comparing results from Lautenschlager et al. 1997b and Lautenschlager et al. 1995, respectively). Species-specific responses of small mammals to treatment have been attributed to changes in near-ground humidity associated with vegetation reductions, although changes in microclimate and vegetation (food and cover) are difficult to separate.

\section{Direct Effects of Herbicide Use}

Small mammals may ingest treated vegetation (seeds, fruits, vegetative parts) or invertebrates that contain residues or be contacted directly by a herbicide during application. However, significant direct contact seems unlikely because many small mammals forage and rest in or below the leaf litter on the forest floor and the bulk of the spray solution is intercepted by the vegetation above that strata, overstory trees, shrubs, and herbs (Thompson et al. 1997). Nevertheless, low-level herbicide residues have been found, at levels below those associated with vegetation, in omnivorous and herbivorous mammals soon after treatment (Newton et al. 1984). Therefore, forest herbicide treatments could directly affect small mammal demographic parameters.

Few studies, however, have examined the direct effects of herbicides on small mammals. Wahlgren (1979) reported that glyphosate had no adverse effects on reproductive parameters in laboratory mice. Similarly, Newton and Dost (1981, 1984) reported that glyphosate did not affect reproduction in laboratory rats. In field studies, glyphosate had no effects on demographic parameters of a deer mouse population in the first year after treatment (Sullivan and Sullivan 1981), and it did not bioaccumulate in mammals (Newton et al. 1984). Sullivan (1990b) assessed growth and survival in control and treatment populations of deer mice and Oregon voles over a five-year period in a coastal coniferous forest and found no direct effect on metabolic or general physiological processes associated with the development of young small mammals. Physiological changes that might have resulted from glyphosate exposure or ingestion were not apparent in demographic attributes at the population level. In a study in an interior cedar-hemlock forest, reproduction, recruitment, body weights, and survival of deer mice were similar in control and glyphosate treatment areas in the two post-treatment years (Runciman and Sullivan 1996).
Sullivan et al. (1998b) investigated potential long-term direct effects of glyphosate in sub-boreal spruce forests. They found that deer mouse and red-backed vole populations in control and treatment areas had similar body mass, total biomass, and proportion (adult males and females) in breeding condition. During the post-treatment years, red-backed voles in control areas had a higher average number of successful pregnancies than those in treated areas. However, estimates of red-backed vole survival were higher in treatment populations, potentially explaining increased vole pregnancies in control areas. The magnitude of observed demographic effects from herbicide treatment on these small mammal species were well within the mean values of natural fluctuations of these variables (Sullivan et al. 1998b).

In an unpublished report, McComb et al. (1997) compared intraperitoneal $\mathrm{LD}_{50}$ for glyphosate in four wild mammal and five wild amphibian species with lab mice (Mus musculus). They concluded that rats seem to be adequate models for seven of the nine species. $\mathrm{LD}_{50} \mathrm{~s}$ were $>800 \mathrm{mg} / \mathrm{kg}$, or about 165 times higher than a dose likely to be received by these species after field applications. Rough-skin newts (Taricha granulosa) and Townsend chipmunks (Tamias townsendii) given sub-lethal doses of glyphosate were marked with radio transmitters and released into unsprayed habitat. Individuals of both species had the same survival and movement patterns as those given a control dose.

\section{Mid-Sized and Large Mammals (Table 6) \\ Snowshoe Hare}

The snowshoe hare (Lepus americanus) is a common mid-sized mammal occupying early- to mid-successional boreal and boreal mixedwood forests across northern North America. In Europe, the "blue" or mountain hare (L. timidus) also prefers forested areas (Walker et al. 1968) and occupies a similar niche to the snowshoe hare. Hares are an important food source for a variety of terrestrial and avian carnivores (Walker et al. 1968, Kurta 1995) that may occupy or be found near treated sites. Understory vegetation density, softwood or hardwood, rather than food supply seems to limit hare populations (Wolff 1980, Litvaitus et al. 1985). However, "dense softwood understories support hare densities greater than do (similar aged) hardwood stands because softwoods provide hare with superior cover from predators and climatic extremes" (Litvaitus et al. 1985). So, although successful conifer release treatments should improve snowshoe hare habitat in the short- and longer-term, the possibility exists that they could reduce the carrying capacity of treated sites for hare.

Hjeljord et al. (1988) and Hjeljord (1994) reported that hare use of treated areas decreased during the first year after a glyphosate treatment, but during the next eight years hare use did not differ from their use of untreated controls. Litvaitus et al. (1985) stated that northern conifer forests are colonized by hare six or seven years after cutting and reach peak population levels 14-18 years later. Sullivan $(1994,1996)$ documented effects on snowshoe hare populations of conifer release of areas that were unsuccessfully regenerated, from one to two decades previously (backlog areas). He concluded that: 1) herbicideinduced alteration in these areas did not affect abundance, reproduction, growth, and survival of snowshoe hare, and 2) backlog areas, 14-21 years after harvest, particularly those with a high component of coniferous species, maintained a vegetative structure sufficient to support hare populations (and presumably associated carnivores) regardless of treatment. 
Although limited studies reviewed by Lautenschlager (1993a, b) have suggested that conifer release treatments applied to young regenerating stands can reduce their carrying capacity for hare, previous research as well as recent work by Potvin et al. (1999) and de Bellefeuille et al. (2001) found that snowshoe hare avoid recently clearcut areas. Seemingly because of that, de Bellefeuille et al. (2001) found no difference in hare use between treatments [naturally regenerated (controls) and plantations released with either brushsaws or glyphosate herbicide] applied to early successional conifer stands in south-central Quebec. Therefore, research findings suggests that neither treatments designed to promote conifer survival and growth (applied soon after establishment) nor treatments designed to release conifers planted 10-20 years previously are likely to reduce stand-level hare populations.

Still, because of the large number of variables involved, standand landscape-level responses may be dramatically different, particularly for a cyclic animal like snowshoe hare. When snowshoe hare populations are high, dispersing individuals would likely use most available habitats regardless of quality, and when populations are low, they would likely occupy only the most preferred habitat. In many northern landscapes dominated by recent clearcuts preferred habitat seems to develop starting 10-15 years after clearcutting (Litvaitus et al. 1985, Potvin et al. 1999) and to be associated with two- to five-meter tall regenerating softwood stands (de Bellefeuille et al. 2001). Because conifer release treatments are designed to ensure the development of these and older conifer stands it seems likely that the most effective treatment (herbicide) is likely to benefit snowshoe hare populations, and those of associated carnivores, to a greater extent than no treatment.

\section{Deer and Moose}

Earlier reviews that examined information about the effects of herbicide treatments on deer and moose focused on studies of browse availability and habitat use (Lautenschlager 1986, 1991, 1992, 1993a,b). In general, deer seem unaffected by herbicide treatment while moose consistently reduce their use of treated areas during the first three to five years after treatment (Lautenschlager et al. 1999). Several recent studies confirm these results.

Trichet et al. (1987) concluded that although bramble (Rubus fruticosus), a staple winter food of roe deer (Capreolus capreolus), was controlled by a herbicide application, the treatment did not change the intensity of area use and browsing pressure became somewhat greater in treated plots. Where bramble was successfully controlled deer densities remained high because deer ate other shrubs. Once brambles recovered (four to five years after treatment), deer demonstrated no preference for either glyphosate-treated or control areas.

Gourley et al. (1990) reported that anti-browsing treatments (structural and chemical, e.g., protective netting, and a repellent, Deer Away ${ }^{\circledR}$ ) provided no growth advantage to planted Douglas-fir, while some of the treatments actually reduced Douglas-fir growth. In contrast, competition control with glyphosate consistently improved Douglas-fir growth, and by the fifth post-treatment year, planted fir averaged twice the biomass of control trees regardless of the degree of browsing by black-tailed deer (Odocoileus hemionus) and elk (Cervus canadensis).

The influence of conifer release with glyphosate on summer forage for white-tailed deer (O. virginianus), one and seven to ten years after treatment, was evaluated by Vreeland et al. (1998) in northwestern Maine. They found that the abundance of leaves of deciduous trees and shrubs was 3.4 times greater on untreated than treated sites one year after treatment, but similar seven to ten years after treatment. Forb abundance was similar on treated and untreated sites one year after treatment, but 2.0 times greater on treated sites seven to ten years after treatment, when total forage availability was 1.2 times greater on glyphosate treated sites. They concluded that although glyphosate initially reduced the abundance of deciduous trees and shrubs, the longer-term positive effect on forbs may result in little net change in overall habitat value for deer.

Collectively, these studies and an earlier study by Sullivan (1985), suggest that deer use of regenerating conifer stands is not reduced by release treatments. That is probably because deer feed extensively on herbs (Crawford et al. 1993), which generally increase in abundance following herbicide treatments.

Much of the recent research into effects of herbicide treatments on moose has examined forage quality (Cumming et al. 1995, Raymond et al. 1996, Raymond and Servello 1997). Results have indicated that dormant-season forage quality is not affected by conifer release with herbicides. Cumming et al. (1995) also reported no differences in digestible protein (DP) or digestible dry matter (DDM), for growing season forage, between herbicide-treated and control plots four and eight years after treatment. However, their data indicate that in treated portions of their eight-year-old study area, DP of trembling aspen was 6\% higher, willow (Salix spp.) was $26 \%$ higher, and red raspberry was $51 \%$ higher. Forage quality was similar among treatments (varying glyphosate rates) in a four-year-old study area of lower site quality.

Interestingly, earlier work by Morgan and McCormack (1973) found that two years after balsam fir (Abies balsamea) transplants were treated with simazine to control surrounding competing vegetation, treated transplants had approximately twice the crude protein and higher ash and moisture levels than did control and fertilizer-treated transplants. This increased nutrition could make treated plants more susceptible to browsing (Morgan and McCormack 1973). However, in Oregon, Gourley et al. (1990) found that five years after glyphosate treatment, planted Douglas-fir volume production was actually $33-50 \%$ greater than on untreated plots, regardless of treatments designed to reduce deer and elk browsing.

Raymond et al. (1996) found that, one to two years after glyphosate treatment, biomass and percent of available deciduous browse eaten by moose were reduced significantly relative to untreated controls. However, seven to eleven years after treatment, both were four to five times greater on treated than untreated clearcuts. Dormant season digestible energy and protein content of moose diets on clearcuts were not significantly affected by treatment. The authors concluded that initial forage reductions may decrease the suitability of clearcuts for moose, but this effect decreases during the next five to nine years as browse availability decreases naturally on untreated sites.

Raymond and Servello (1997) studied red maple (Acer rubrum) dormant-season twigs and found that neutral and acid detergent fibre concentrations were $18 \%$ less and lignincutin was $8 \%$ greater in twigs from herbicide-treated areas than those from untreated areas. Predicted digestible dry matter and digestible energy values were $7 \%$ greater in glyphosate injured (but not killed) than uninjured twigs. Crude protein concentrations 


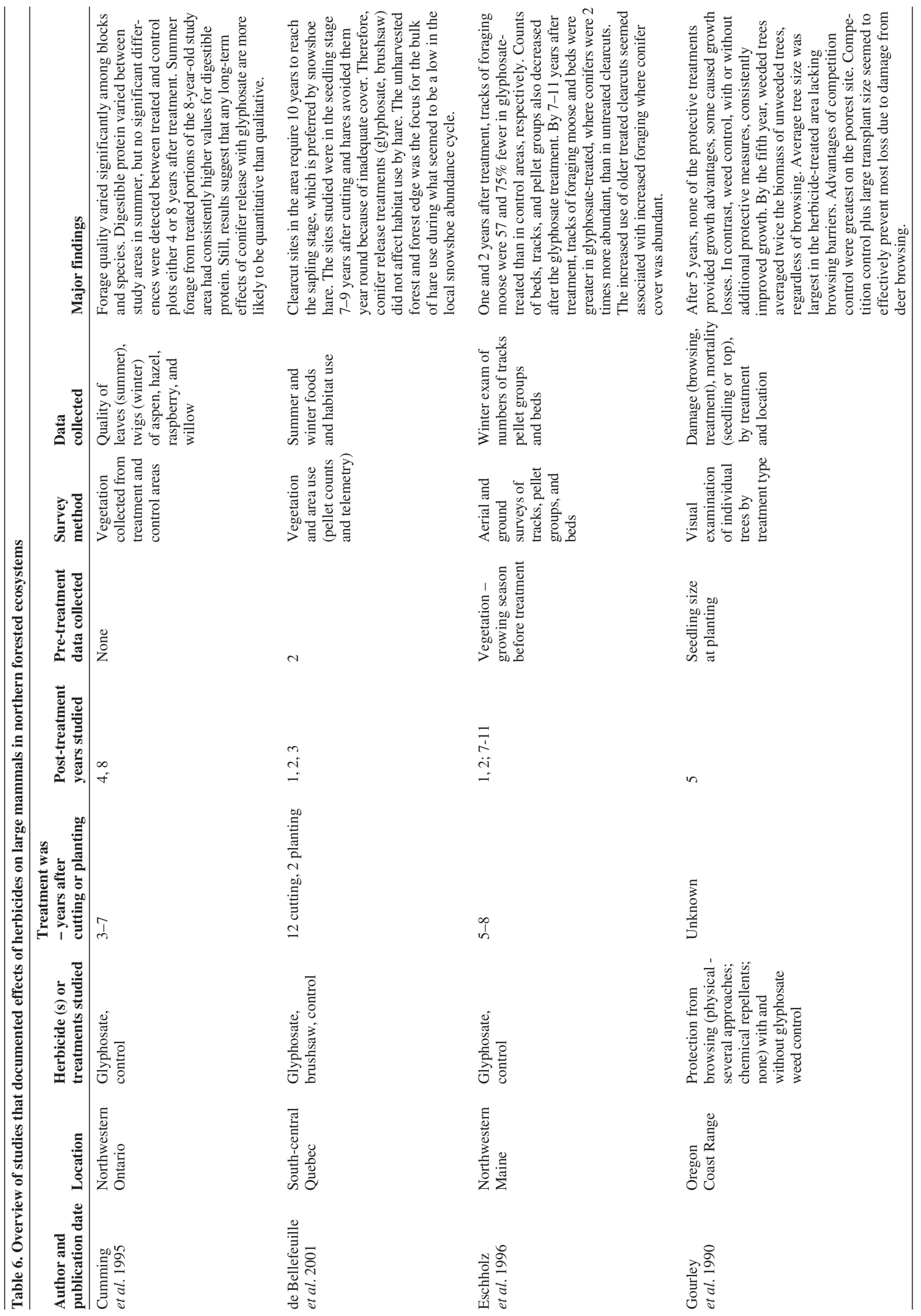




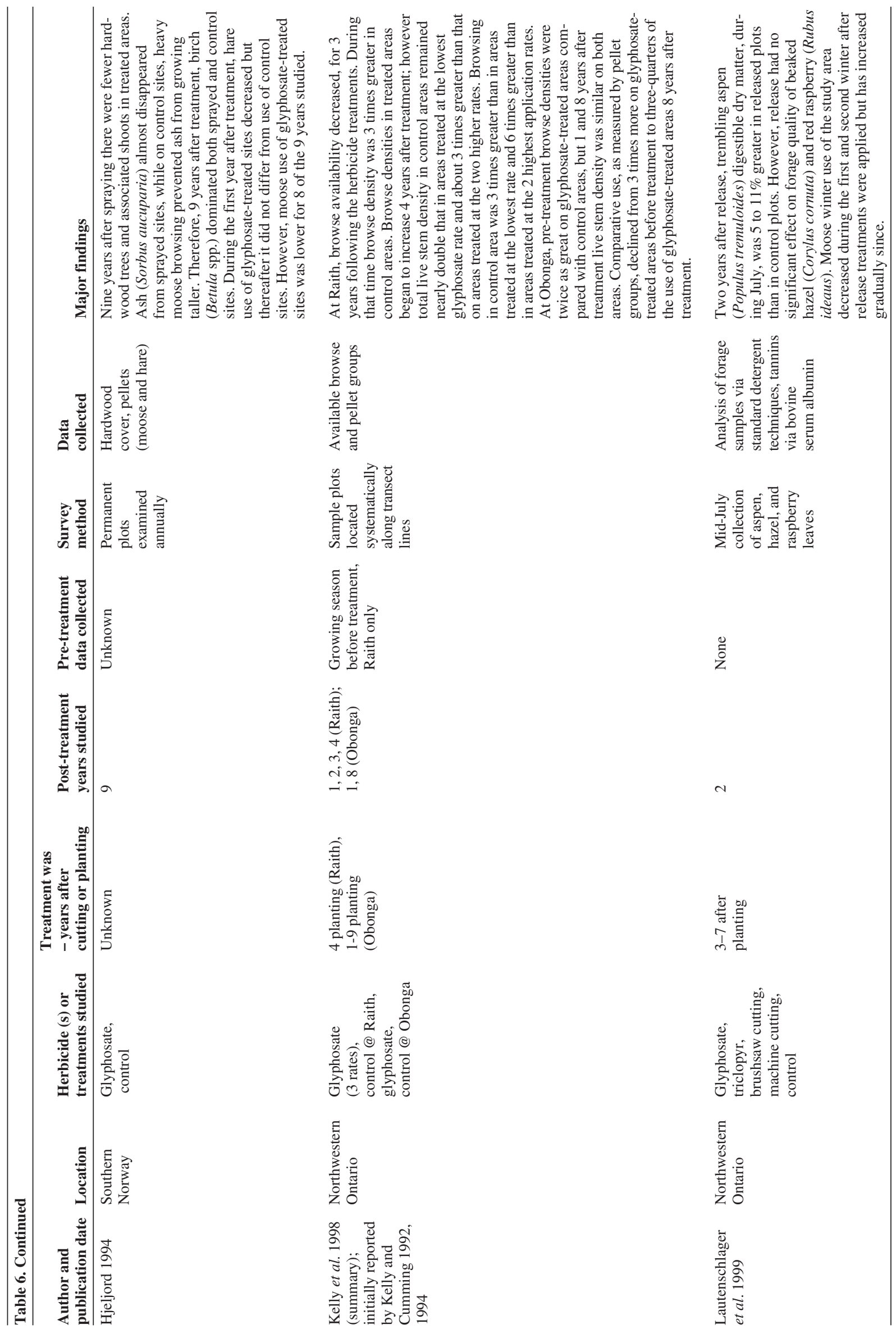




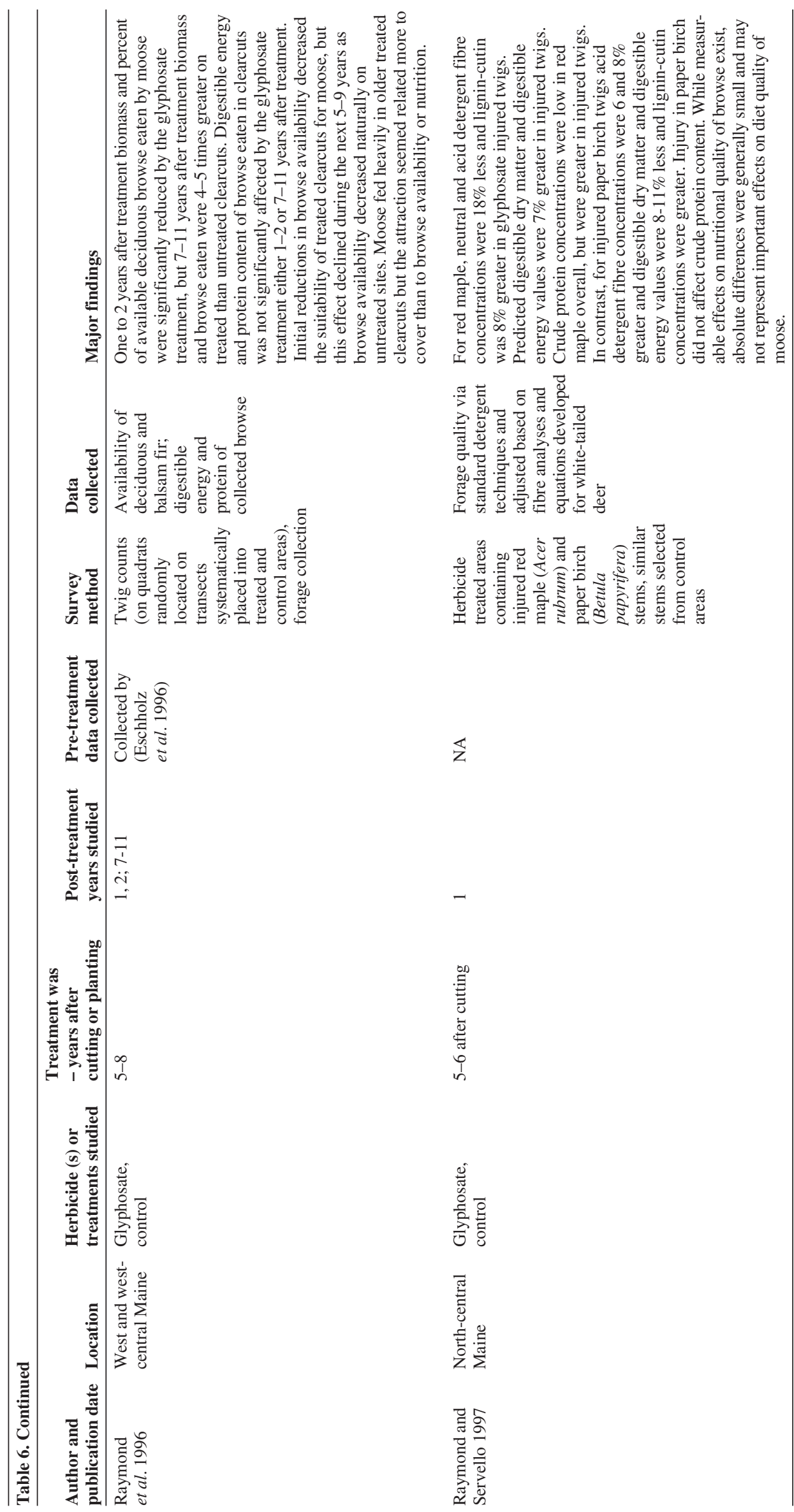




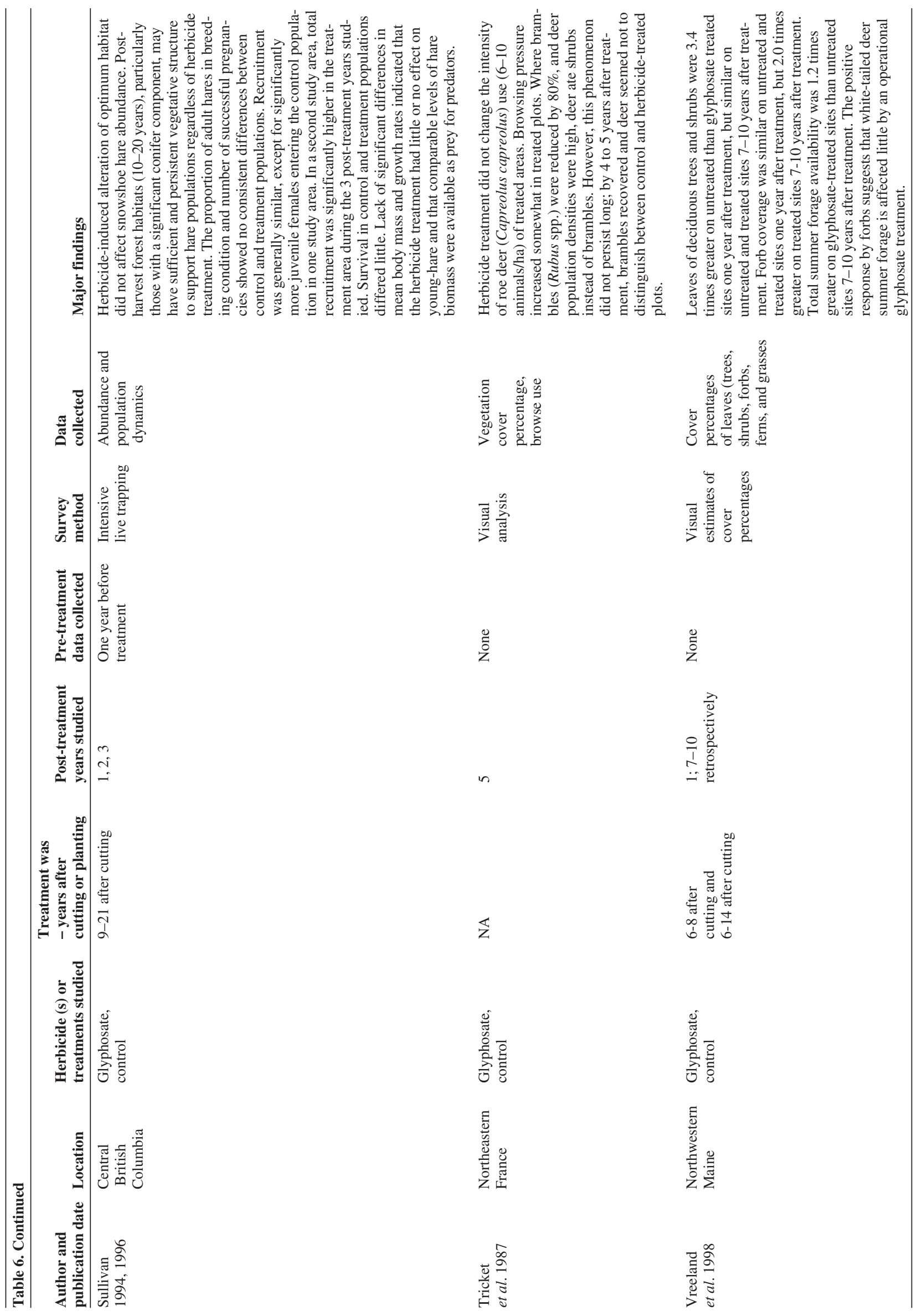


were low in red maple overall but were greater in injured than uninjured twigs. Analysis of dormant-season paper birch (Betula papyrifera) twigs showed that injured twigs had neutral and acid detergent fibre concentrations that were 6 and $8 \%$ greater and digestible dry matter and digestible energy values that were $8-11 \%$ less in injured twigs. Lignin-cutin concentrations were greater in injured twigs, and crude protein content was not affected by injury. The authors concluded that while measurable effects on nutritional quality of browse existed, absolute differences generally were small and not biologically significant.

Two years after several conifer release alternatives were applied, Lautenschlager et al. (1999) examined DP and DDM of quaking aspen, hazel (Corylus cornuta), and red raspberry foliage collected during July. Only trembling aspen, which had the highest DDM and DP of the species examined, showed statistically significant differences among treatments. Aspen DDM was five to eleven percent and DP was 34-49\% greater in released plots than in control plots (Lautenschlager et al. 1999). Although not statistically significant, DP also was consistently higher for hazel and red raspberry in released plots. However, the lack of statistically significant differences in DDM and DP among treatments for two of the three species examined suggests that, through time, biomass availability of forage species continues to be a realistic way to predict the effects of conifer-release treatments on forage (Lautenschlager et al. 1999).

Stand-level reductions in forage biomass availability (commonly 50-70\% during the first year after treatment - Newton et al. 1987; Kelly and Cumming 1992,1994; Raymond et al. 1996, Kelly et al. 1998) and reductions in habitat use by moose have consistently followed conifer release treatments (Lautenschlager 1992, Lautenschlager et al. 1999). Most studies confirm that those reductions persist up to four years after treatment. However, Kelly et al. (1998) suggested that on some sites in northwestern Ontario, forage availability and habitat use reductions may continue through eight years after treatment. Eschholz et al. (1996), and Raymond et al. (1996), using a combination of designed and retrospective studies, reported that biomass of deciduous browse eaten by moose and habitat use during winter decreased soon after glyphosate release treatments, while seven to eleven years after treatment, availability increased in treated clearcuts. Raymond et al. (1996), who found heavy browsing in older treated areas, concluded, as did Lautenschlager (1986, 1993a, b) and Newton et al. (1989), that those areas were more attractive to moose than control areas. However, Raymond et al. (1996) suggested that the attraction likely was related more closely to the successful establishment of conifer cover than to the availability or nutritional content of the browse.

Studies from Maine (Newton et al. 1989, Eschholz et al. 1996, Raymond et al. 1996, Vreeland et al. 1998), however, may not be comparable to studies elsewhere in the North because much of that research has been conducted in naturally regenerated earlysuccessional spruce-fir stands. Studies in other northern areas are commonly conducted in plantations, which tend to receive greater silvicultural attention and be released sooner than naturally regenerated stands. The biomass of competing vegetation in young naturally regenerated stands generally is older, greater, and more difficult to control. Thus, conifer release in plantations may not consistently lead to the longer-term increased area use by moose documented for naturally regenerated conifer stands.

\section{Palatability, Forage Consumption, and Meat Quality}

A concern of those who gather meat from wild sources is its potential contamination. Meat consumption could potentially pose a health risk to humans if wild game consumed herbicidetreated forage and retained significant percentages of the active ingredients in tissues normally consumed by hunters and their families.

Results to date indicate that animals do not avoid herbicidetreated forage. Sullivan and Sullivan (1979) fed captive blacktailed deer both control and glyphosate-treated forage and found that deer showed no preference. Campbell et al. (1981) found that when glyphosate was applied at silviculturally effective rates, black-tailed deer did not avoid treated foliage. Jones and Forbes (1984) reported that treating forage with glyphosate had no significant effects on use by domestic sheep (daily intake, mean meal size, or consumption rate). Lloyd (1989) reported that moose eat herbicide-damaged plants when damage is light or moderate but do not browse severely damaged or dead plants. Because large wild animals will consume treated forage, secondary effects on humans must be considered.

In a study of the fate of glyphosate in a forest ecosystem, Newton et al. (1984) concluded that exposure of mammalian herbivores, carnivores, and omnivores varied with food preferences. However, all species examined by Newton et al. (1984) had visceral and body contents of glyphosate at or below observed levels in ground cover and litter. This suggests that glyphosate does not accumulate in higher trophic levels. Brewster et al. (1991) documented metabolism of glyphosate in rats fed $10 \mathrm{mg} / \mathrm{kg}$ body weight and found that $35-40 \%$ of the administered dose was absorbed from the gastrointestinal (GI) tract; while 60-65\% was initially eliminated via urine and faeces. They also reported that any residue in the body after seven days (approximately $1 \%$ of the administered dose) was associated with bones. Because there was little evidence of metabolism, Brewster et al. (1991) concluded that virtually no toxic metabolites of glyphosate were produced.

Legris and Couture (1991) examined flesh samples from snowshoe hare, white-tailed deer, and moose harvested inside or close to areas that had been treated with glyphosate approximately two months before sampling. Although $0.146 \mu \mathrm{g} / \mathrm{g}$ was found in one sample of moose flesh, the authors concluded that this was likely due to contamination, because the 31 other samples showed no detectable residues. Based primarily on data from snowshoe hare, they concluded that glyphosate ingested with vegetation was mainly eliminated through the urinary and faecal tracts, and that consuming meat or organs such as liver of animals that have fed in or near treated areas poses little risk to humans.

These findings, along with the recent registration by Health/Agriculture Canada of Roundup ${ }^{\circledR}$ (the formulated glyphosate product used in agriculture which is nearly identical to the product registered as Vision ${ }^{\circledR}$ for forestry use) for preharvest forage and cereal grain desiccation treatments (Roundup ${ }^{\circledR}$ label) demonstrate that there are no science-based health concerns associated with eating wild animals that may have consumed glyphosate-treated vegetation, domestic animals fed treated agricultural forage, or cereal grain following treatment.

\section{Landscape-Level Considerations}

After cutting, forests are generally regenerated, either naturally (seeds or sprouts) or artificially (planting). Clearcutting 
Table 7. Annual average area of forest affected by different disturbance types in New Brunswick, Ontario, and British Columbia

\begin{tabular}{|c|c|c|c|}
\hline Disturbance & New Brunswick & Ontario & British Columbia \\
\hline Clearcut (ha) ${ }^{1}$ & 81632.5 & 191642.8 & 195651.6 \\
\hline Fires (ha) ${ }^{1}$ & $\begin{array}{c}6116.4 \\
(7 \% \text { of cut })\end{array}$ & $\begin{array}{l}188348.4 \\
\text { (98\% of cut) }\end{array}$ & $\begin{array}{c}49561.3 \\
(25 \% \text { of cut })\end{array}$ \\
\hline $\begin{array}{l}\text { Insects defoliation }{ }^{1} \\
\text { (moderate to severe (ha) }\end{array}$ & $\begin{array}{c}459.3 \\
(0.5 \% \text { of cut })\end{array}$ & $\begin{array}{c}17651.8 \\
(9.2 \% \text { of cut })\end{array}$ & $\begin{array}{c}728.5 \\
(0.3 \% \text { of cut })\end{array}$ \\
\hline $\begin{array}{l}\text { Site Preparation }{ }^{2} \text { (Total - } \\
\text { burn, mechnical, and other) }\end{array}$ & $\begin{array}{c}10673.5 \\
(13.1 \% \text { of cut })\end{array}$ & $\begin{array}{c}91788.0 \\
(47.9 \% \text { of cut })\end{array}$ & $\begin{array}{c}151825.5 \\
(77.6 \% \text { of cut })\end{array}$ \\
\hline Weeding and cleaning ${ }^{2}$ & $\begin{array}{c}12572.8 \\
(15.4 \% \text { of cut })\end{array}$ & $\begin{array}{c}78984.0 \\
(34.2 \% \text { of cut })\end{array}$ & $\begin{array}{c}29380.0 \\
(16.3 \% \text { of cut })\end{array}$ \\
\hline
\end{tabular}

${ }^{1}$ For 1985 to 1994.

${ }^{2}$ For 1993 to 1994.

Source: CCFM 1995b.

continues to be the most commonly used method of harvesting even-aged forests in Canada (CCFM 1995b, Potvin et al. 1999), and it has been recognized as "an acceptable timber management practice for the boreal forest" (Koven and Martel 1994). Herbicide use commonly follows clearcutting. Both cutting and herbicide use are stand-level treatments that affect vegetation (species, abundance, structure), and associated biotic and abiotic components on sites. Landscape consequences of standlevel treatments are the sum of those effects plus the result of the character, extent, and interactions with landscapes around them (context). Consequences for specific components and systems increase as treatment size and related influences increase (Allen and Hoekstra 1992), but are modified by context.

Extensive efforts, such as planting and tending, are often required to replace harvested forests with pre-harvest forest types. Historically, in northern ecosystems, regeneration efforts were nonexistent; although they are now more common, they are often incomplete or insufficient (Lautenschlager 2000). As a result, and because of changes in wildfire frequency and intensity, the composition of northern forests has changed from conifer dominated to mixed-wood or intolerant hardwood dominated (Carleton 2000, Lautenschlager and Voigt 2001). The problem is not that those forests have been harvested, rather regeneration following harvesting seems to be unlike that which followed the natural disturbances. Serious effort is required if managers hope to maintain conifers across harvested northern landscapes. That effort, however, has commonly been insufficient. For example, in 1993 and 1994, only 22\% of clearcut forested land in Canada was "weeded and cleaned" using herbicides (CCFM 1995b). Still, even those efforts have not always resulted in successful conifer re-establishment. Hearnden et al. (1992) examined areas that were clearcut between 1970 and 1990 in Ontario and found major conversions from previously conifer-dominated to hardwood-dominated stands, even after the clearcuts were planted or seeded with conifers and many were released with herbicides.

Carleton (2000) summarized the survey by Hearnden et al. (1992) and his own work in northeastern Ontario and concluded that selective logging has led to an increase in shade-tolerant tree species and a decline in pioneer conifers while clearcut logging has converted forests dominated by pioneer, fire-tolerant conifers to those dominated by pioneer, fire-tolerant, broadleaved tree species. Interestingly, this loss of conifers has been documented in Ontario, a province where herbicides are used extensively (Table 7). For instance, in 1994, Ontario treated nearly as many hectares with herbicides as all other Canadian provinces combined (CCFM 1995b). The loss of conifers across northern ecosystems would undoubtedly be greater if herbicides were not used; however, it has been documented wherever forests have been harvested in the north (Harvey and Bergeron 1989, Kuhnke 1989, Drapeau et al. 2000, Lautenschlager and Voigt 2001). A variety of approaches, including planting larger stock and planting immediately after harvesting as well as earlier release with an appropriate herbicide to ensure conifer survival and growth could reverse this trend in the future.

In addition to human-caused disturbances, like cutting and herbicide treatments, fires, insect damage, and disease affect stands and landscapes. Although commonly human-caused, fire is the natural disturbance cited as the major factor shaping landscape development in the north (Holling 1973, Heinselman 1981, Johnson 1992). However, the ecological consequences of many of the fires that burn today seem unlike those of fires that burned in the past. This may be because previously common low intensity ground fires are now often successfully suppressed and decades of suppression has led to an abundance of fuels, and related higher intensity fires. Fires presently affect differing percentages of forested land across Canada. Each year, fire occurs on an equivalent of approximately 25,100 , and $7 \%$ of the area harvested in British Columbia, Ontario, and New Brunswick, respectively (Table 7).

Compared with fire, insect defoliation, the other commonly cited natural disturbance agent affecting northern ecosystems, affects much less of the Canadian landscape. Although western pine beetle (Dendroctus ponderosae) is presently decimating parts of British Columbia and the eastern spruce budworm caused extensive damage to New Brunswick forests in the past, insect defoliation seems to have played less of a role in British Columbia and New Brunswick, recently, where an average of $0.3 \%$ and $0.5 \%$, respectively, of the area clearcut annually is defoliated, than in Ontario, where $9 \%$ is defoliated (Table 7). Like the interaction between fire suppression and the destructiveness of today's fires, decades of forest harvesting coupled with insect and fire suppression have also likely altered the ecological consequences of present-day insect outbreaks at stand and landscape scales.

Clearly, vegetation responses to any disturbance, including silvicultural treatments, like cutting and conifer release must be documented at the stand level. But, meaningful conclusions come 
only from placing those responses into an increasingly broader-scale context (Flather and Sauer 1996, Bissonette 1997). Although a limited number of ecological studies have recently attempted to document landscape-level effects of forest management on key biotic components (e.g., Potvin et al. 1999, Mitchell et al. 2001), those studies seldom examine effects of clearcutting per se and have not examined effects of herbicide treatments. In addition, studies have seldom attempted to put effects of either clearcutting or conifer release with herbicides into context much beyond the local landscape. Therefore, studies that attempt to draw broader-scale conclusions relative to effects of herbicide treatments on biota are of interest.

After examining 156 cutblocks (totalling approximately 10000 ha) harvested in north-central British Columbia between 1970 and 1988, Lloyd (1994), in an unpublished report, attempted to draw such conclusions. Of the blocks examined, two thirds were treated (or planned for treatment) in whole or in part with glyphosate. Therefore, one might conclude that about two thirds of the recently cut landscape of northern British Columbia, receives a herbicide treatment. However, the Canadian Council of Forest Ministers (1995b) Compendium of Canadian Forestry Statistics shows that in British Columbia and across Canada (the broader, and much broader context, respectively) the percentage of clearcuts treated with herbicides tends to be much lower. Indeed, British Columbia treated (weeding and cleaning) only about $16 \%$ of the forest land clearcut annually from 1984 to 1994 (Table 7). In addition, in the area examined by Lloyd (1994), during the last seven years, only about $22 \%$ of clearcuts were released, about a third $(9 \%)$ with herbicides (Lautenschlager, unpublished notes). Therefore, in that area less than one quarter of the cut area is released and less than one tenth is released with herbicides.

At broad scales, Canadian forests continue to regenerate after a combination of human- and natural-caused disturbances, but the escalating loss of conifers from these ecosystems is socially and ecologically troubling. Even as our climate seems to change (Parker et al. 2000), many argue that efforts should be made to maintain functioning ecosystems similar to those that were found historically across landscapes (Brown et al. 2001). Such maintenance, however, will require developing replacement stands of appropriate species and structures that provide acceptable, potentially historical, forest cover patterns. Successful conifer re-establishment is based on an interaction among stocking, treatment efficacy, and site quality (Lautenschlager 1993a, b). At the stand level, complete success at re-establishing conifers has been unusual (Frisque et al. 1978, Kuhnke 1989, Hearnden et al. 1992, Carleton 2000). That establishment, however, it is often a legal requirement and may be the most rapid way to increase forest production in northern ecosystems (Lautenschlager 2000). Although there are any number of potential explanations for the loss of conifers from northern forests, herbicide use presently provides the most cost-effective, environmentally safe way to reverse that loss and accomplish restoration goals.

\section{Discussion and Conclusions \\ Long-Term Trends}

North American forests have developed and changed dramatically since the retreat of glaciers 10000 to 12000 years ago. Over the last few thousand years, those forests have experienced periods of dramatic warming and cooling
(Miller and Woolfenden 1999). At broad scales, climatic forces influence the development of vegetation. That development is further influenced by a variety of local abiotic (climate, soil, fire, etc.) and biotic (plant, animal, disease, etc.) factors. During the last century, harvesting large trees was one of the major biotic influences on North American forests. However, human management of northern forests is not new. Natives used fire and other tools to manage vegetation and associated animals in these ecosystems for thousands of years (Day 1953, Pyne 1982, DeGraaf and Miller 1996). In addition, wildfires (both natural and human-caused), insect outbreaks, and diseases periodically changed the composition of large expanses of northern forests during that time (Holling 1973).

Therefore, the forests found in northern North America by early European settlers resulted from the previous climate (e.g., the Little Ice Age), repeated natural and human-caused disturbances, and potentially reduced human disturbance during the previous two centuries caused by introduced diseases that decimated native populations (Kay 1998). Stand-replacing wildfires provided favourable seedbeds for conifer establishment and growth, favouring stress-tolerant conifers and early-successional fruit-producing low shrubs over the less stress-tolerant, more nutrient-demanding hardwoods. By removing ground-level competition and smaller weaker conspecifics, the more common surface fires, which were both natural and native-set, tended to favour established larger conifers e.g., pines across much of the north and Douglas-fir in the Pacific Northwest.

As forest harvesting became increasingly common, post-harvest forest establishment and growth increasingly failed to track historical post-disturbance successional patterns. Specifically, hardwoods began to increase and prosper at the expense of conifers. Before the rise of conservation, few were concerned about those changes. However, as interest in basic management, wise use, conservation, and the maintenance of ecosystems across landscapes slowly emerged, managers attempted to ensure that ecosystems both provided products for human use and returned to their pre-harvest composition. It soon became evident, however, that conifers, even when planted, suffered without the more violent natural and human-caused disturbances and related site changes that previously allowed them to prosper. Historically, natural disturbances such as insect attacks or wildfires commonly allowed the development of advance conifer regeneration or prepared sites for early-successional species establishment and growth while sometimes minimizing competition. Planting without competition control was often unsuccessful because competing vegetation tended to reduce or eliminate the planted conifers.

Thus, silvicultural practices, including the use of herbicides, were developed to encourage growth of conifers after harvesting. Herbicide active ingredients mixed in water were sprayed over naturally regenerated conifers and conifer plantations to reduce non-conifer competition. This alone, or in combination with other silvicultural practices (e.g., site preparation), helped conifers become established, survive, and grow after harvest. Although these efforts contributed to conifer replacement in many treated stands, they were not always successful. In addition, many harvested stands remained untreated leading to an additional loss of conifers. The loss of conifers from northern landscapes, and their short- and long-term replacement by hardwoods, continues wherever northern landscapes are harvested. 


\section{Vegetation}

Herbicide treatments have become a valuable tool of operational foresters because they can, relatively inexpensively and effectively, increase conifer survival and growth. Non-conifer vegetation is commonly reduced for one to four years following broadcast herbicide treatments; longer-term reductions of some species (e.g., blueberry) seem possible. Fungi, however, seem relatively unaffected by herbicides. Although moss and lichen reductions have been recorded, they are most dramatic followed experimental, as opposed to operational, treatments. The extent and length of non-conifer reductions, including reductions in browse and fruit-bearing species, depends on active ingredient, application rate, time, weather, and site. However, post-treatment vegetation changes, especially longer-term changes, are poorly documented and need more study. Short-term reductions are commonly species and/or vegetation group-specific, while longer-term changes often are linked to conifer stocking, site quality, and the ability (or lack thereof) of conifers to dominate treated sites. The duration of non-conifer reductions that do occur seemingly decrease as site quality increases. Although vegetation reductions following herbicide treatments are common, the literature illustrates large variability in vegetation abundance found following "identical" (chemical and rate) treatments (Lautenschlager 1993a). It is clear that herbicide treatments applied to regenerating stands do not reduce, and sometimes increase, stand and landscape level plant species richness (diversity). If conifers (planted or natural) dominate a site they may reduce the presence and abundance of other species. Still, site-level changes must be viewed from a landscape perspective at increasingly broader scales. Management practices that lead to large early-successional stands in the midst of older-successional stands may be desirable, while practices that simply add one more early-successional stand to an abundance of such stands may be less desirable (Hunter 1990).

\section{Terrestrial Invertebrates}

Below-ground and surface-active terrestrial invertebrates, insects, arachnids, gastropods, and microbial processes seem relatively unaffected by herbicide release treatments. Some components (carabid beetles) increase, while others (slugs and snails) have become slightly less active on the soil surface. As would be expected, foliar-dependent insects are reduced in abundance following successful treatments, but start to recover as broad-leaved plants re-invade or begin growing again on treated sites. As with plants, invertebrate species are seldom eliminated, and new species often arrive to occupy newly created niches. Available data suggest no reason for concern about the presence and condition of terrestrial invertebrates following herbicide treatments in northern ecosystems.

\section{Amphibians and Reptiles}

Although little information exists about effects of herbicide treatments on amphibians and reptiles, that which is available suggests that because of application timing, and the habitat preference and secretive nature of these animals, they, especially amphibians, are unlikely to be exposed, or absorb enough of any herbicide to lead to direct toxicity. To date, habitat changes caused by site preparation and conifer release treatments have not affected any of the species examined in the wild. The garter snake is the only reptile studied to date, and limited data suggest that it is common and reproductively active in and around released regenerating stands.

\section{Songbirds}

Abundance of species that prefer early successional deciduous cover generally decreases one to two years after conifer release treatments, whereas densities of species that avoid that cover tend to increase. Abundance of species that decrease soon after treatment often recovers during the following three years. Species-specific responses are linked to treatment-related habitat changes and not to herbicide treatments per se. Densities of some species have been reduced as much or more by brushsaw cutting as by herbicide treatments. However, population increases or decreases associated with herbicide treatments seem to last longer than those associated with brushsaw cutting.

\section{Small Mammals}

Changes following application of herbicides are related to habitat changes (vegetation composition and structure), and they affect small mammal abundance and species composition indirectly. However, depending on site quality, abundance of some species (red-backed vole and sometimes the common shrew) are reduced for one to three years after treatment. Under normal use scenarios, the active ingredients in the herbicides commonly used to manage northern forest ecosystems do not affect the general health (e.g., survival, growth, reproduction) of small mammals or any of the other animals examined. In studies where short-term control versus treatment differences in abundance were found, the magnitude of observed differences was well within the range of natural fluctuations. Even when herbicide treatments cause major changes in plant species abundance, plant and small mammal diversity seems relatively unaffected.

\section{Mid-Sized and Large Mammals}

Few studies have documented effects of site preparation and conifer release treatments on snowshoe hare; however, hares seldom use early successional plantations, the focus for most conifer release treatments, and seem to be unaffected by later treatments (10-20 years after regeneration is initiated). Hares should benefit from conifer release because that treatment is designed to aid the development of preferred, conifer-dominated, habitat. Deer also seem to be unaffected or to benefit from conifer release treatments. In contrast, treatments often reduce biomass of moose forage and habitat use of treated areas by moose for three to seven years. Though, for several years after treatment, forage quality (DP, DDM) in treated areas is equal to or superior to that in control areas. However, moose populations are commonly controlled more by hunting mortality than by habitat availability (Rempel et al. 1997), and moose in naturally regenerated conifer stands have consistently used older ( $\geq$ seven-yearold) treated areas more than similar-aged untreated areas. Although large- (deer and moose) mid-sized, and small-mammals consume glyphosate-treated foliage when it is encountered, residues are quickly eliminated through digestive processes and treatments should pose no threat to humans or carnivores.

\section{Successional Time Comparisons}

Although most of the studies reviewed were established to compare responses among treatments, successional time following treatments within and among studies often vary con- 
siderably, i.e., investigators compare stands of different successional ages and structures. Specifically, within-study controls are consistently successionally older than the treatment types to which they are compared. For example, Lautenschlager et al. (1998) applied treatments four to seven years after site preparation and planting; controls in that study were therefore successionally four to seven years older than treatment areas because, to varying degrees, the treatments reinitiated succession. Even by three years after treatment, Lautenschlager et al. (1998) compared treated areas where the bulk of vegetation was successionally three years old with controls that were successionally six to nine years old. Little wonder researchers find differences when such comparisons are made; the wonder is that they find so few.

Those involved in disturbance-related studies should consider examining their results in terms of successional time as well as among treatments. When results of the studies reviewed for this paper are examined through successional time, few or no differences among treatments on biotic components are observed. For instance, Santillo et al. (1989) reported "fewer invertebrates, especially herbivorous insects, on herbicidetreated clearcuts." In that study, total insect captures, one and three years after the glyphosate treatments, studied were 446 and 644, respectively, and 900 in the untreated control area. However, the control was clearcut six years before the study began and when plotted in successional time (one, three, and six years) after disturbance, total captures reported by Santillo et al. (1989) fit a nearly straight line, increasing through time. Keeping that in mind, as researchers examine differences between treated and untreated areas in the future, their conclusions should be based on changes through successional as well as chronological time.

\section{Stand versus Landscape Changes}

Most studies of environmental responses to herbicides have been conducted at a sub-stand level. Researchers commonly subdivided stands into smaller units to achieve statistical replication, but results from these small-scale versus truly operational-scale treatments have never been tested. In addition, forest management practices in general, and site preparation and conifer release with herbicides in particular, must be viewed relative to the landscape mosaic and the desired future forest conditions. What may be unacceptable in certain stands or areas may be desirable in others, depending on how it fits into present or developing forest landscape patterns and local needs (Lautenschlager et al. 2000). Herbicide treatments are commonly used to encourage conifer establishment, survival, and growth; yet at broad scales, across boreal and boreal mixedwood ecosystems, conifers have consistently been replaced by hardwoods since Europeans began harvesting in these ecosystems. Therefore, although concern about forest management treatments favouring conifers has been expressed, conifers have actually been losing their position of dominance in most northern ecosystems. Those interested in maintaining or restoring conifer ecosystems, in the future, likely will find herbicides useful for accomplishing their goals.

\section{Considerations for the Future}

Many members of the public viewing areas recently treated with spray solutions containing a herbicide product assume that effects on plants and animals are dramatic, long lasting, and neg- ative. However, the scientific literature published to date provides no evidence for those assumptions. Rather, it shows that herbicide treatments affect plants both directly and indirectly and those changes to habitat (quantity and quality) affect animals indirectly. Therefore, depending on habitat requirements, populations of animal species may increase, decrease, or remain relatively unchanged following treatments.

Some of the problems identified by Lautenschlager (1993a) have been addressed by subsequent research, but longer-term work at appropriate scales, similar to that documenting responses of wildlife to clearcutting (Potvin et al. 1999), is still needed. Researchers documenting biotic consequences of silvicultural treatments also must identify if the silvicultural objective(s) of the treatment(s) were achieved; e.g., did conifer crop trees become established, survive, or grow better because of the treatment? If so, how much better and for how long? Both biotic and silvicultural consequences must be documented before the full effect of existing or proposed treatments can be determined. Addressing operational-scale questions, which according to Baskerville (1994) forestry researchers have seldom done, has become even more difficult with increased public concern about and demand for involvement in natural resource management decisions (Lautenschlager 1999c). In addition, operational realities associated with site-preparation and conifer release can and have changed over time.

This review will be most valuable for decisions in the future if the management practices examined continue. However, changes in management have been made and should be expected to continue. For instance, using patch as opposed to broadcast treatments has become more common and there is increasing interest in dividing landscapes into specific management zones, including zones dedicated to intensive silviculture (Lautenschlager 2000). Therefore, in the future, although the herbicide active ingredients will likely change little, treatments designed to increase fibre production may be applied sooner and more often and treatment areas may be at a higher density within designated zones. Unfortunately, we know little about the consequences of these or the combination of treatments, such as site preparation, fertilization, genetic improvement, and conifer release, identified by Lautenschlager (2000) on crop survival, growth, or the environment. To provide meaningful results for the future, researchers will need to document those consequences as new operational regimes emerge, are implemented, or change.

Still, economic realities suggest to some (Benson 1988, Oliver 1999, McKenney 2000) that management intensity in our cooler, less productive northern ecosystems may not increase substantially in the near future. If not, managers may simply strive to become more effective with existing treatments, potentially optimizing timing, improving delivery systems, and/or improving the effectiveness of existing active ingredients. Even those improvements, however, could pose problems for those hoping to use the synthesized information presented here to predict biotic consequences of improved treatments. However, this review should be useful for drawing conclusions about standard treatments and outlining expectations for restoration efforts, a use of herbicides that will likely become increasingly important as managers attempt to re-establish conifers across northern landscapes. Regardless of the management approach taken, in addition to study designs that document effects of operational treatments on environmental components of concern and translate fine-scale findings to broader-scale realities, increas- 
ingly social considerations will need to be integrated into research and management plans (Lautenschlager 1999c, Lautenschlager et al. 2000).

\section{Acknowledgements}

We thank Trudy Vaittinen for preparing graphics; Abby Obenchain and Wendeline Price for editorial suggestions; Milo Mihajlovich, Taylor Scarr, and two anonymous reviewers for their critical reviews and very helpful comments on an earlier draft of this manuscript.

\section{References}

Addison, J.A. 1996. The impacts of conventional and alternative vegetation management practices on soil fauna. Unpublished Final Report - on file at the Ontario Forest Research Institute, Sault Ste. Marie. Allen, T.F.H. and T.W. Hoekstra. 1992. Toward a Unified Ecology. Columbia University Press, New York, NY. 384 p.

Atkinson, D. 1985. Toxicological properties of glyphosate - a summary. In E. Grossbard and D. Atkinson (eds.). The Herbicide Glyphosate. pp. 127-133. Butterworths, London.

Baskerville, G. L. 1994. Gaelic poetry for deaf seagulls-encore. For Chron. 70(5): 562-564.

Bell, F.W., R.A. Lautenschlager, R.G. Wagner, D.G. Pitt, J.W. Hawkins and K.R. Ride. 1997. Motor-manual, mechanical, and herbicide release affect early successional vegetation in northwestern Ontario. For. Chron. 73(1): 61-68.

Bell, F.W., and S.G. Newmaster. 1998. Fallingsnow ecosystem project: floral richness, abundance and diversity. In R.G. Wagner and D.G Thompson (eds.) Third International Forest Vegetation Management Conference: Popular Summaries. pp. 45-48. Min. Nat. Res., Ont. For. Res. Inst., Sault Ste. Marie, ON.

Benson, C.A. 1988. A need for extensive forest management. For. Chron. 64(5): 421-430.

Berrill, M., S. Bertram, L. McGillvray, M. Kolohon and B. Pauli. 1994. Effects of low concentrations of forest-use pesticides on frog embryos and tadpoles. Environ. Toxicol. Chem. 13: 657-664.

Binkley, C.S. 1997. Preserving nature through intensive plantation forestry: The case for forest land allocation with illustrations from British Columbia. For. Chron. 73(5): 553-559.

Bissonette, J.A. 1997. Scale-sensitive ecological properties: historical context, current meaning. In J.A. Bissonette (ed.). Wildlife and landscape ecology: effects of pattern and scale. pp. 3-31. SpringerVerlag. New York, NY.

Boateng, J.O., S. Haeussler and L. Bedford. 2000. Boreal plant community diversity 10 years after glyphosate treatment. Western. J. Appl. For. 15(1): 15-26.

Bogart, J.P., R.A. Lautenschlager and F.W. Bell. 1995. Effects of alternative vegetation management treatments on amphibians and reptiles in the Fallingsnow ecosystem. In K Wood, and C. Hollstedt (comps.). The Fallingsnow Ecosystem Workshop. pp. 32-33. Ont. Min. of Nat. Res., Northwest Sci. Tech., Thunder Bay, ON.

Brewster, D.W., J.J. Warren and W.E. Hopkins II. 1991. Metabolism of glyphosate in Sprague-Dawley rats: Tissue distribution, identification, and quantification of glyphosate-derived materials following a single oral dose. Fund. and Appl. Tox. 17: 43-51.

Brown, N.R., R.F. Noss, D.D. Diamond and M.N. Myers. 2001. Conservation biology and forest certification. J. For. 99(8): 18-25.

Campbell, D.L., J. Evans, G.D. Lindsey and W.E. Dusenberry. 1981. Acceptance by black-tailed deer of foliage treated with herbicides. Res. Pap. PNW-290, USDA For. Serv., Olympia, WA.

Canadian Council of Forest Ministers (CCFM) 1995a. Defining sustainable forest management - A Canadian approach to criteria and indicators. Nat. Res. Can., Can. For. Serv., Ottawa, ON.

Canadian Council of Forest Ministers (CCFM) 1995b. Compendium of Canadian Forestry Statistics. Nat. Res. Can., Can. For. Serv., Ottawa, ON.
Carleton, T.J. 2000. Vegetation responses to the managed forest landscape of central and northern Ontario. In A.H. Perera, D.L. Euler and I.D. Thompson (eds.). Ecology of a Managed Terrestrial Landscape: Patterns and Processes of Forest Landscapes in Ontario. pp. 178-197. Univ. of British Columbia Press, Vancouver, BC.

Clawson, M. 1975. Forests for Whom and for What. John Hopkins University Press. Englewood Cliffs, NJ.

Cole, E.C., W.C. McComb, M. Newton, C.L. Chambers and J.P. Leeming. 1997. Response of amphibians to clearcutting, burning, and glyphosate application in the Oregon coast range. J. Wildl. Manage. 61: 656-664.

Cole, E.C., W.C. McComb, M. Newton, L.P. Leeming and C.L. Chambers. 1998. Response of small mammals to clearcutting, burning, and glyphosate application in the Oregon coast range. J. Wildl. Manage. 62(4): 1207-1216.

Crawford, H.S., R.A. Lautenschlager, M.R.Stokes and T.L. Stone. 1993. Effects of forest disturbance and soil depth on digestible energy for moose and white-tailed deer. Res. Pap. NE-682. USDA For. Serv., Northeastern For. Exp. Sta, Radnor, PA.

Cumming, H.G., C.P. Kelly, R.A. Lautenschlager and S. Thapa. 1995. Effects of conifer release with Vision ${ }^{\circledR}$ (glyphosate) on moose forage quality. Alces 31: 221-232.

Drapeau, P, A. Leduc, J.-F. Giroux, J-P. L. Savard, Y. Bergeron and W. L. Vickery. 2000. Landscape-scale disturbances and changes in bird communities of boreal mixed-wood forests. Ecol. Monog. 70(3): 423-444.

Day, G.M. 1953. The Indian as an ecological factor in the notheastern forest. Ecology 34(2): 329-346.

de Bellefeuille, S., L. Belanger, Jean Huot and A. Cimon. 2001. Clear-cutting and regeneration practices in Quebec boreal balsam fir forest: effects on snowshoe hare. Can. J. For. Res. 31: 41-51.

DeGraaf, R.M. and R.I. Miller. 1996. Conservation of Faunal Diversity in Forested Landscapes. Chapman \& Hall, New York, NY. Duchesne, L.C., R.A. Lautenschlager and F.W. Bell. 1999. Effects of clear-cutting and plant competition control methods on carabid (Coleoptera: Carabidae) assemblages in northwestern Ontario. Env. Mon. and Ass. 56: 87-96.

Easton, W.E. and K. Martin. 1998. The effect of vegetation management on breeding bird communities in British Columbia. Ecol. Appl. 8(4): 1092-1103.

Eschholz, W.E., F.A. Servello, B. Griffith, K. Raymond and W.B. Krohn. 1996. Winter use of glyphosate-treated clearcuts by moose in Maine. J. Wildl. Manage. 60(4): 764-769.

Feng, J.C. and D.G. Thompson. 1989. Persistence and dissipation of glyphosate in foliage and soils of a Canadian coastal forest watershed. In P.E. Reynolds (ed.). Proceedings of the Carnation Creek herbicide workshop. pp. 65-87. Nat. Res. Can., Can. For. Serv., For. Pest Manage. Institute, Sault Ste. Marie, ON.

Flather, C.H. and J.R. Sauer. 1996. Using landscape ecology to test hypotheses about large-scale abundance patterns in migratory birds. Ecology 77: 28-35.

Freedman, B. 1991. Controversy over the use of herbicides in forestry, with particular reference to glyphosate usage. J. Environ. Sci. Health C8: 277-286.

Freedman, B., R. Morash and D. MacKinnon. 1993. Short-term changes in vegetation after the silvicultural spraying of glyphosate herbicide onto regenerating clearcuts in Nova Scotia, Canada. Can. J. For. Res. 23: 2300-2311.

Frisque, G., G.F. Weetman and C. Clemmer. 1978. Reproduction and trial projected yields 10 years after cutting 36 pulpwood stands in eastern Canada. Tech. Rep. No. TR-23. For. Eng. Res. Inst. Can. Gagné, N., L. Bélanger and J. Huot. 1999. Comparative response of small mammals, vegetation, and food sources to natural regeneration and conifer release treatments in boreal balsam fir stands of Quebec. Can. J. For. Res. 29: 1128-1140. 
Giesy, J.P., S. Dobson and K.R. Solomon. 2000. Ecotoxicological risk assessment for Roundup ${ }^{\circledR}$ herbicide. Rev. Environ. Contam. Toxicol. 167: 35-120.

Gourley, M., M. Vomocil and M. Newton. 1990. Forest weeding reduces the effect of deer browsing on Douglas-fir. For. Ecol. Manage. 36: 177-186.

Hamilton, A.N., C.A. Bryden and C.J. Clement. 1991. Impacts of glyphosate application on grizzly bear forage production in the Coastal Western Hemlock Zone. FREA Rept. 165. B.C. Min. of For., Nat. Res. Can., Can. For. Serv., Victoria, BC.

Harvey, B.D. and Y. Bergeron. 1989. Site patterns of natural regeneration following clear-cutting in northwestern Quebec. Can. J. For. Res. 19: 1458-1469.

Hawkins, J.W., M.W. Lankester, R.A. Lautenschlager and F.W. Bell. 1997. Effects of alternative conifer release treatments on terrestrial gastropods in northwestern Ontario. For. Chron. 73(1): 91-98.

Hearnden, K.W., S.V. Millson and W.C. Wilson. 1992. A Report on the Status of Forest Regeneration: Ontario Independent Forest Audit. Ont. Min. of Nat. Res., For. Manage. Br., Sault Ste. Marie, ON.

Heinselman, M.L. 1981. Fire intensity and frequency as factors in the distribution and structure of northern ecosystems. In H.A. Mooney et al. (eds.) Proceedings of the conference on fire regimes and ecosystem properties. Gen. Tech. Rep. WO-26. USDA For. Serv., Washington, DC.

Hildebrand, L.D., D.S. Sullivan and T.P. Sullivan. 1980. Effects of Roundup herbicide on populations of Daphnia magna in a forest pond. Bull. Environ. Contam. Toxic. 25: 353-357.

Hjeljord, O. 1994. Moose (Alces alces) and mountain hare (Lepus timidus) use of conifer plantations following glyphosate application. Nor. J. Agr. Sci. 8(3-4): 181-188.

Hjeljord, O., V. Sahlgaard, V.E. Enge, M. Eggestad and S. Gronvold. 1988. Glyphosate application in forest-ecological aspects. VII. The effect on mountain hare (Lepus timidus) use of a forest plantation. Scan. J. For. Res. 3: 123-127.

Holling, C.S. 1973. Resilience and stability of ecological systems. Ann. Rev. Ecol. and Syst. 4: 1-23.

Horsley, S.B. 1994. Regeneration success and plant species diversity of Allegheny hardwood stands after Roundup application and shelterwood cutting. North. J. Appl. For. 11(4): 109-116.

Hunter, M.L. Jr. 1990. Wildlife, Forests, and Forestry - Principles of Managing Forests for Biological Diversity. Prentice Hall, Englewood Cliffs, NJ.

Huston, A.P.C, S. Visser and R.A. Lautenschlager. 1998a. Microbial processes and fungal community structure in soils from clear-cut and unharvested areas of two mixedwood forests. Can. J. Bot. 76: 630-640.

Huston, A.P.C, S. Visser and R.A. Lautenschlager. 1998b. Response of microbial processes and fungal community structure to vegetation management in mixedwood forest soils. Can. J. Bot. 76: 2002-2010.

Jobidon, R. 1990. Short-term effect of three mechanical site preparation methods on species diversity. Tree Plant. Notes 41(4): 39-42. Johnson, E.A. 1992. Fire and Vegetation Dynamics: Studies from North American Boreal Forest. Cambridge, Cambridge University Press, Cambridge, UK.

Jones, R. and J.M. Forbes. 1984. A note on effects of glyphosate and quinine on the palatability of hay for sheep. Anim. Prod. 38: 301-303. Kay, C.E. 1998. Are ecosystems structured from the top-down or bottom-up: a new look at an old debate. Wildl. Soc. Bull 26(3): 484-498. Kelly, C.P. and H.G. Cumming. 1992. Effects of an aerial application of Vision ${ }^{\circledR}$ on moose (Alces alces) browse - first year results. Alces 28: 101-110.

Kelly, C.P. and H.G. Cumming. 1994. Effects of Vision ${ }^{\circledR}$ application on moose winter browsing and hardwood vegetation. Alces 30: 173-188.
Kelly, C.P., H.G. Cumming and R.A. Lautenschlager. 1998 Recovery of woody moose browse 3,4 , and 8 years and performance of crop trees 1 to 4 years after aerial application of glyphosate. In R.G. Wagner and D.G. Thompson (comps.) Third International Conference on Forest Vegetation Management: Popular summaries. pp.136-138. Ont. Min. Nat. Resour., Ont. For. Res. Inst., Sault Ste. Marie, ON. For. Res. Info. Pap. No 141.

Kostyk, B., S. Greifenhagen and F.W. Bell. 1997. Effects of alternative conifer release treatments on yellow-headed spruce sawfly defoliation. For. Res. Note No. 57. Ont. Min. Nat. Res., Ont. For. Res. Inst., Sault Ste. Marie, ON.

Koven, A. and E. Martel. 1994. Class Environmental Assessment by the Ministry of Natural Resources for Timber Management on Crown lands in Ontario, EA-87-02.

Kurta, A. 1995. Mammals of the Great Lakes Region. University of Michigan Press, Ann Arbor, Michigan.

Kuhnke, D.H. 1989. Silviculture statistics for Canada: an 11-year summary. Inf. Rep. NOR-X-301 Nat. Res. Can., Can. For. Serv., Northern. For. Cent., Edmonton, AB.

Lautenschlager, R.A. 1986. Forestry, herbicides, and wildlife. In J.A. Bissonette, (ed.). Is Good Forestry Good Wildlife Management? pp. 299-308. Misc. Pub. 689. Maine Agr. Expt. Sta., Univ. of Maine, Orono, ME

Lautenschlager, R.A. 1990. Red raspberry (Rubus idaeus L.) ecology: germination, growth, and interactions with white spruce (Picea glauca (Moench) Voss) growth [PhD dissertation]. Univ. of Maine, Orono, ME.

Lautenschlager, R.A. 1991. Response of wildlife in northern ecosystems to conifer release with herbicides. Misc. Rep. 362. Maine Agr. Exp. Sta., Univ. of Maine, Orono, ME.

Lautenschlager, R.A. 1992. Effects of conifer release with herbicides on moose: Browse production, habitat use, and residues in meat. Alces 28: 215-222.

Lautenschlager, R.A. 1993a. Response of wildlife to forest herbicide applications in northern coniferous ecosystems. Can. J. For. Res. 23: 2286-2299.

Lautenschlager, R.A. 1993b. Effects of conifer release with herbicides on wildlife (A review with an emphasis on Ontario's forests). For. Res. Info. Pap. 111. Ont. Min. Nat. Res., Ont. For. Res. Inst., Sault Ste. Marie, ON.

Lautenschlager, R.A. 1995. Competition between forest brush and planted white spruce in north-central Maine. North. J. Appl. For. 12(4): 163-167.

Lautenschlager, R.A. 1999a. Intensive silviculture - Part of Ontario's new "Living Legacy." For. Chron. 75(3): 535.

Lautenschlager, R.A. 1999b. Environmental resource interactions affect red raspberry growth and its competition with white spruce. Can. J. For. Res. 29: 906-916.

Lautenschlager, R.A. 1999c. Improving long-term forest ecology research for the $21^{\text {st }}$ century. For. Chron. 75(3): 477-480.

Lautenschlager, R.A. 2000. Can intensive silviculture contribute to sustainable forest management in northern ecosystems? For. Chron. 76(2): 283-295.

Lautenschlager, R.A. 2001. Science and certification. For. Chron. 77(1): 151-152.

Lautenschlager, R.A. and M.L. McCormack Jr. 1989. Herbicide release may increase species diversity. In R.D. Briggs et al. (eds.). Forest and Wildlife management in New England - What can we afford? Maine Agr. Exp. Sta., Univ. of Maine, Orono, ME.

Lautenschlager, R.A., C. Hollstedt and F.W. Bell. 1995. Effects of herbicide, manual, and annual release of young jack pine on vegetation and small mammals in northwestern Ontario. New Zealand Forest Research Institute, Rotorua, NZ, Bulletin No. 192: 149-151. Lautenschlager, R.A., F.W. Bell, R.G. Wagner and J.A. Winters. 1997a. The Fallingsnow ecosystem project: Comparing conifer release alternatives in northwestern Ontario. For. Chron. 73(1): 35-38. 
Lautenschlager, R.A., F.W. Bell and R.G. Wagner. 1997b. Alternative conifer release treatments affect small mammals in northwestern Ontario. For. Chron. 73(1): 99-106.

Lautenschlager, R.A., F.W. Bell, R.G. Wagner and P.E. Reynolds. 1998. The Fallingsnow Ecosystem Project: Documenting the consequences of conifer release alternatives. J. For. 96 (11): 20-27.

Lautenschlager, R.A., W.J. Dalton, M.L. Cherry and J.L. Graham. 1999. Conifer release alternatives increase aspen forage quality in northwestern Ontario. J. Wildl. Manage. 63(4): 1320-1326. Lautenschlager, R.A., H. MacLeod, C. Hollstedt and D. Balsillie. 2000. Examining the Specifics approach to identifying indicators of sustainable natural resource management in Ontario, Saskatchewan, and British Columbia. For. Chron. 76(5): 725-738.

Lautenschlager, R.A. and D. Voigt. 2001. Effects of forest regeneration practices on wildlife. In R.G. Wagner and S.J. Colombo (eds.). Regenerating the Canadian Forest: Principles and Practice for Ontario. pp. 521-540. Fitzhenry \& Whiteside, Markham, ON.

Legris, J. and G. Couture. 1991. Résidus de glyphosate dans le gibier (lièvre, orignal et cerf de Virginie) suite à des pulvérisations en milieu forestier en 1988. Min. des For., Serv. Des Anal. Env., Gouv. Du Québec. 91-3016.

Lindgren, P.M.F. and T.P. Sullivan. 2001. Influence of alternative vegetation management treatments on conifer plantation attributes: abundance, species diversity, and structural diversity. For. Ecol. and Manage. 142: 161-180.

Litvaitis, J.A., J.A. Sherburne and J.A. Bissonette. 1985. Influence of understory characteristics on snowshoe hare habitat use and density. J. Wildl. Manage. 49: 866-873.

Lloyd, R.A. 1989. Assessing the impact of glyphosate and liquid hexazinone on moose browse species in the Skeena region [Unpublished report]. B.C. Min. Env., Fish and Wildl. Br., Smithers, BC.

Lloyd, R.A. 1994. Implications for wildlife of past herbicide use in the Babine Lake area [Unpublished report]. B.C. Min. Env., Pest. Cont. Br., Smithers, BC.

McComb, W.C., L.. Curtis, K. Bentson, M. Newton and C.L. Chambers. 1997. Toxicity of glyphosate herbicide to terrestrial mammals and amphibians of the Oregon Coast Range [Unpublished report]. Dept. For. Sci., Oregon State Univ., Corvallis, OR.

Messier, C. and D.D. Kneeshaw. 1999. Thinking and acting differently for sustainable management of the boreal forest. For. Chron. 75(6): 929-938.

McKenney, D. 2000. What's the economics of intensive silviculture? For. Chron. 76(2): 275-281.

Mihajlovich, M. 2001. Triclopyr Herbicide - A technical bibliography of non-target effects. Incremental Forest Technologies Ltd., Edmonton, $\mathrm{AB}$

Miller, C.I. and W.B. Woolfenden. 1999. The role of climate change in interpreting historical variability. Ecol. Appl. 9(4): 1207-1216.

Mitchell, D.G., P.M. Chapman and T.J. Long. 1987. Seawater challenge testing of Coho Salmon smolts following exposure to Roundup herbicide. Env. Tox. Chem. 6: 875-878.

Mitchell, M.S., R.A. Lancia and J.A. Gerwin. 2001. Using landscape-level data to predict the distribution of birds on a managed forest: effects of scale. Ecological Applications 11(6): 1692-1708.

Moola, F.M., A.U. Mallik and R.A. Lautenschlager. 1998. Effects of conifer release treatments on growth and fruit production of $\mathrm{Vac}$ cinium spp. in northwestern Ontario. Can. J. For. Res. 28: 841-851. Morgan, R.H. and M.L. McCormack Jr. 1973. Simazine enhances balsam fir growth but contributes to deer damage. Tree Planters' Notes 24: 11-13.

Morrison, M.L. and E.C. Meslow. 1983. Impacts of forest herbicides on wildlife: toxicity and habitat alteration. Trans. North Am. Wildl. Nat. Res. Conf. 48: 175-185.

Newmaster, S.G., F.W. Bell and D.H. Vitt. 1999. The effects of glyphosate and triclopyr on common bryophytes and lichens in northwestern Ontario. Can. J. For. Res. 29: 1101-1111.
Newton, M. and F.N. Dost. 1981. Environmental effects of vegetation management practices on DNR forest lands. Wash. Dept. Nat. Res., Olympia, WA.

Newton, M. and F.N. Dost. 1984. Biological and physical effects of forest vegetation management. Final report . Washington State Dept. Nat. Res., Olympia, WA.

Newton, M., K.M. Howard, B.R. Kepsas, R. Danhaus, C.M. Lottman and S. Dubelman. 1984. Fate of glyphosate in an Oregon USA forest ecosystem. J. of Agr. Food Chem. 32: 1144-1151.

Newton, M., M.L. McCormack, Jr., R.L. Sajdak and J.D. Walstad. 1987. Forest vegetation problems in the northeast and Lake States/Provinces. In J.D. Walstad and P.J. Kuch (eds.). Forest Vegetation Management for Conifer Production. pp. 77-103. John Wiley, New York, NY.

Newton, M., E.C. Cole, R.A. Lautenschlager, D.E. White and M.L. McCormack Jr. 1989. Browse availability after conifer release in Maine's spruce-fir forests. J. Wildl. Manage. 52: 643-649.

Newton, M., F. Roberts, A. Allen, et al. 1990. Deposition and dissipation of three herbicides in foliage, litter, and soil of brushfields in southwestern Oregon. J. Agric. Food Chem. 38: 574-583.

Newton, M., E.C. Cole, D.E. White and M.L. McCormack, Jr. 1992. Young spruce-fir forests released by herbicides. I. Response of hardwoods and shrubs. Nor. J. Appl. For. 9(4): 126-130.

Oliver, C.D. 1999. The future of the forest management industry: Highly mechanized plantations and reserves or a knowledge-intensive integrated approach? For. Chron. 75(2): 229-245.

Parker, W.C., S.J. Colombo, M.L. Cherry, M.D. Flannigan, S. Greifenhagen, R.S. McAlpine, C. Papadopol and T. Scarr. 2000. Third millennium forestry: What climate change might mean to forests and forest management in Ontario. For. Chron. 76(3): 445-463. Pitt, D.G., R.A. Fleming and D.G. Thompson. 1992. Glyphosate efficacy on eastern Canadian forest weeds. Part II: deposit-response relationships and crop tolerance. Can. J. For. Res. 22: 1160-1171.

Pitt, D.G., D.G. Thompson, N.J. Payne and E.G. Kettela. 1993. Response of woody eastern Canadian forest weeds to fall foliar treatments of glyphosate and triclopyr herbicides. Can. J. For. Res. 23 :2490-2498. Pitt, D.G., A.E. Morneault, P. Bunce and F.W. Bell. 2000. Five years of vegetation succession following vegetation management treatments in a jack pine ecosystem. North. J. Appl. For. 17(3): 100-109.

Potvin, F., R. Courtois and L. Bélanger. 1999. Short-term response of wildlife to clear-cutting in Quebec boreal forest: multiscale effects and management implications. Can. J. For. Res. 29: 1120-1127.

Prezio, J.R. 1997. Effects of alternative conifer release treatments on terrestrial gastropods of regenerating spruce plantations [MS Thesis]. Lakehead Univ., Thunder Bay, ON.

Prezio, J.R., M.W. Lankester, R.A. Lautenschlager and F.W. Bell. 1999. Effects of alternative conifer release treatments on terrestrial gastropods of regenerating spruce plantations. Can. J. For. Res. 29: 1141-1148.

Pyne, S.J. 1982. Fire in America. Princeton University Press, Princeton, NJ.

Radosevich, S.R. and K. Osteryoung. 1987. Principles governing plant-environment interactions. In J.D. Walstad and P.J. Kuch (eds.) Forest Vegetation Management for Conifer Production. pp. 105-156. John Wiley, New York, NY.

Raymond, K.S., F.A. Servello, B. Griffith and W.E. Eschholz. 1996. Winter foraging ecology of moose on glyphosate-treated clearcuts in Maine. J. Wildl. Manage. 60: 753-763.

Raymond, K.S. and F.A. Servello. 1997. Nutritional quality of glyphosate-injured browse for moose in Maine. Alces 33: 181-185. Rempel, R.S., P.C. Elkie, A.R. Rogers, and M.J. Gluck. 1997. Timber-management and natural-disturbance effects on moose habitat: landscape evaluation. J. Wildl. Manage. 61: 517-524.

Reynolds, P.E., J.A. Simpson, R.A. Lautenschlager, F.W. Bell, A.M. Gordon, D.A. Buckley and D.A. Gresh. 1997. Alternative conifer release treatments affect below- and near-ground microclimate. For. Chron. 73(1): 75-82. 
Roshon, R.D., J.H. McCann, D.G. Thompson and G.R. Stephenson. 1999. Effects of seven forestry management herbicides on Myriophyllum sibiricum, as compared with other nontarget aquatic organisms. Can. J. For. Res. 29: 1158-1169.

Roy D.N., S.K. Konar, S. Banerjee and D.A. Charles. 1989 Uptake and persistence of the herbicide glyphosate $\left(\right.$ Vision $\left.^{\circledR}\right)$ in fruit of wild blueberry and red raspberry. Can. J. For. Res. 19: 842-847.

Runciman, J.B., and T.P. Sullivan. 1996. Influence of alternative conifer release treatments on habitat structure and small mammal populations in south central British Columbia. Can. J. For. Res. 26: 2023-2034.

Santillo, D.J., D.M. Leslie, Jr. and P.W. Brown. 1989. Response of small mammals and habitat to glyphosate application on clear-cuts. J. Wildl. Manage. 53: 164-172.

Seymour, R.S. and M.L. McCormack Jr. 1989. Having our forest and harvesting it too: The role of intensive silviculture in resolving forest land use conflicts. In R.D. Briggs et al. (eds.) Forest Wildlife Management in New England - What can we afford? pp. 207-213 Maine Agri. Exp. Sta. Misc. Rep. 336. Univ. Maine, Orono, ME. Seymour, R.A. and M.L. Hunter Jr. 1992. New forestry in eastern spruce-fir forests: Principles and applications to Maine. Misc. Pub. 716. Maine Agri. Exp. Sta., Univ. of Maine, Orono, ME.

Scrivener, J. C. and S. Carruthers. 1989. Changes in the invertebrate populations of the main stream and back channels of Carnation Creek, British Columbia, following spraying with the herbicide Roundup (glyphosate). In P.E. Reynolds (ed.) Proceedings of the Carnation Creek Herbicide Workshop. pp. 263-272. FRDA Report 063. B.C. Min. of For., Nat. Res. Can, Can. For. Serv. Sault Ste. Marie, ON.

Simard, S. and J. Heinemann. 1996. Nine-year response of Douglas-fir and the mixed hardwood-shrub complex to chemical and manual release treatments on an ICHmw2 site near Salmon Arm. FRDA Rep. 257. BC Min. of For., Nat. Res. Can., Can. For. Serv., Victoria, BC.

Smith, D.M. 1986. The Practice of Silviculture (8th ed.). John Wiley, New York, NY.

Smith, D.M., B.C. Larson, M.J. Kelty and P.M.S. Ashton. 1997. The Practice of Silviculture: Applied Forest Ecology. John Wiley, New York, NY.

Sullivan, D.S. T.P. Sullivan and T. Basalputra. 1981. Effects of Roundup herbicide on diatom populations in the aquatic environment of a coastal forest. Bull. Env. Contam. Toxic. 26: 91-96.

Sullivan, D.S. and T.P. Sullivan. 2000. Non-target impacts of the herbicide glyphosate: A compendium of references and abstracts $\left(5^{\text {th }}\right.$ ed.). Information report, Applied Mammal Research Institute, Summerland, BC.

Sullivan, T.P. 1985. Effects of glyphosate on selected species of wildlife. In E. Grossbard and D. Atkinson (eds.). The Herbicide Glyphosate. pp. 96-125. Butterworths, London, UK.

Sullivan, T.P. 1990a. Demographic responses of small mammal populations to a herbicide application in coastal coniferous forest: Population density and resiliency. Can. J. Zool. 68: 874-883.

Sullivan, T.P. 1990b. Influence of forest herbicide on deer mouse and Oregon vole population dynamics. J. Wildl. Manage. 54: 566-576. Sullivan, T.P. 1994. Influence of herbicide-induced habitat alteration on vegetation and snowshoe hare populations in sub-boreal spruce forest. J. Appl. Ecol. 31: 717-730.

Sullivan, T.P. 1996. Influence of forest herbicide on snowshoe hare population dynamics: reproduction, growth, and survival. Can. J. For. Res. 26: 112-119.

Sullivan, T.P. and J.O. Boateng. 1996. Comparison of small-mammal community responses to broadcast burning and herbicide application in cutover forest habitats. Can. J. For. Res. 26:462-473.

Sullivan, T.P. and D.S. Sullivan 1979. The effects of glyphosate herbicide on food preference and consumption in black-tailed deer. Can. J. Zool. 57: 1406-1412.
Sullivan, T.P. and D.S. Sullivan. 1981. Response of a deer mouse population to a forest herbicide application: Reproduction, growth, and survival. Can. J. Zool. 59: 1148-1154.

Sullivan, T.P., R.A. Lautenschlager and R.G. Wagner. 1996. Influence of glyphosate on vegetation dynamics in different successional stages of sub-boreal spruce forest. Weed Tech. 10:439-446. Sullivan, T.P., D.S. Sullivan, R.A. Lautenschlager and R.G. Wagner. 1997. Long-term influence of glyphosate herbicide on demography and diversity of small mammal communities in coastal coniferous forest. Northwestern Sci. 71(1): 6-17.

Sullivan, T.P., R.G. Wagner, D.G. Pitt, R.A. Lautenschlager and D.G. Chen. 1998a. Changes in diversity of plant and small mammal communities after herbicide application in sub-boreal spruce forest. Can. J. For. Res. 28: 168-177.

Sullivan, T.P., C. Nowotny, R.A. Lautenschlager and R.G. Wagner. 1998b. Silvicultural use of herbicide in sub-boreal spruce forest: implications for small mammal population dynamics. J. Wildl. Manage. 62: 1196-1206.

Sullivan, T.P., D.S. Sullivan, E.J. Hogue, R.A. Lautenschlager and R.G. Wagner. 1998c. Population dynamics of small mammals in relation to vegetation management in orchard agroecosystems: compensatory responses in abundance and biomass. Crop Prot. 17: 1-11. Swindel, B.F., L.F. Conde and J.E. Smith. 1984. Species diversity: Concept, measurement, and response to clearcutting and site-preparation. For. Ecol. Manage. 8: 11-22.

Taylor, N.W. (Chair). 1999. Competing realities: The boreal forest at risk. Report of the sub-committee on boreal forest of the standing Senate committee on agriculture and Forestry. Ottawa, ON.

Thompson, D.G., D.G. Pitt, R.A. Fleming and E.G. Kettela. 1992. Glyphosate efficacy on eastern Canadian forest weeds. Part I experimental design and on-target deposit. Can. J. For. Res. 22: 1151-1159.

Thompson, D.G., D.G. Pitt, B. Staznik, N.J. Payne, D. Jaipersaid, R.A. Lautenschlager and F.W. Bell. 1997. On-target deposit and vertical distribution of aerially released herbicides. For. Chron. 73(1): 47-59. Trichet, P. B. Boisaubert, H. Frochot and J.F. Picard. 1987. Impact of herbicide treatments against bramble Rubus fruticosus Lagg on roe deer Capreolus capreolus L. Gibier Faune Sauvage 4: $165-188$.

Vreeland, J.K., F.A. Servello and B. Griffith. 1998. Effects of conifer release with glyphosate on summer forage abundance for deer in Maine. Can. J. For. Res. 28: 1574-1578.

Wagner, R.G., J. Flynn, R. Gregory, C.K. Mertz and P. Slovic. 1998. Acceptable practices in Ontario's forests: Differences between the public and forestry professionals. New For. 16(2): 139-154.

Wagner, R.G., G.H. Mohammed and T.L. Noland. 1999. Critical period of interspecific competition for northern conifers associated with herbaceous vegetation. Can. J. For. Res. 29: 890-897.

Wahlgren, J.R. 1979. The effects of the herbicide Roundup ${ }^{\circledR}$ on reproduction in mice. [BS Agric. Thesis]. Univ. British Colombia, Vancouver, B.C.

Walker, E.P. et al. 1968. Mammals of the World (2 ${ }^{\text {nd }}$ Ed.) Vol. II. Johns Hopkins, Baltimore MD.

Walstad, J.D., and P.J. Kuch. 1987. Vegetation Management for Conifer Production. John Wiley, New York, NY.

Ward, J.L., Y.H. Prevost, R.A. Lautenschlager and F.W. Bell. 1998. Effects of alternative conifer release treatments on epigeal insects, Coleoptera, Carabidae, and non-insectan arthropods in northwestern Ontario. In R. Wagner and D. Thompson (comps.). Third International Conference on Forest Vegetation Management, Popular Summaries. pp. 351-353. Info. Pap. No. 141. Ont. Min. Nat. Res., Ont. For. Res. Inst., Sault Ste. Marie, ON.

Williams, G.M., R. Kroes and I.C. Munro. 2000. Safety evaluation and risk assessment of the herbicide Roundup and its active ingredient, glyphosate, for humans. Reg. Tox. Pharm. 31: 117-165.

Willick, M.L. 2001. Forest sustainability: Ontario combines science, policy and consensus. For. Chron. 77(1): 65-68. 
Wolff, J.O. 1980. The role of habitat patchiness in the population dynamics of snowshoe hares. Ecol. Monogr. 50: 111-130.

Woodcock, J. 1997. Effects of conifer release on breeding songbirds - 1996 report: Fallingsnow Ecosystem Project. Unpublished report on file at the Ontario Forest Research Institute, Sault Ste. Marie, ON. Woodcock, J., R.A. Lautenschlager, F.W. Bell and J.P. Ryder. 1997. Indirect effects of conifer release alternatives on songbird populations in northwestern Ontario. For. Chron. 73(1): 107-112.
Woodcock, J., D.G. Pitt, U. Runnesson, F.W. Bell and R.A. Lautenschlager. 1998. GIS analysis of songbird/vegetation relationships. In R. Wagner and D. Thompson (comps.). Third International Conference on Forest Vegetation Management, Popular Summaries. pp. 363-365 Info. Pap. No. 141. Ont. Min. Nat. Res., Ont. For. Res. Inst., Sault Ste. Marie, ON. 